UDK: 929.52Stjepović-Skočibuha

711.4(497.5Suđurad)

94(497.5Šipan)"15"

Primljeno: 4. 9. 2020.

Prihvaćeno: 5. 5. 2021.

Izvorni znanstveni rad

https://doi.org/10.22586/pp.v40i60.11829

Mara Marić

Dubravka Mirošević **

\title{
Utjecaj obitelji Stjepović-Skočibuha na strukturiranje naselja Suđurađ na otoku Šipanu
}

U radu se predstavlja utjecaj obitelji Stjepović-Skočibuha na uobličavanje naselja Suđurađ na otoku Šipanu kraj Dubrovnika. Prikazan je društveni, gospodarski i kulturni kontekst otoka Šipana u 16. stoljeću s posebnim osvrtom na razvoj naselja Suđurađ. Prezentirani su biografski podaci rodočelnika obitelji Stjepović-Skočibuha koji su zaslužni za izgradnju dva reprezentativna ladanjsko-gospodarska zdanja u naselju koja su vremenom postala temeljni orijentiri Suđurđa. Polazišna hipoteza istraživanja jest da su ladanjski sklopovi Toma, a posebno Vice Stjepovića-Skočibuhe znatno utjecala na uobličavanje naselja. Analizirane su stilske karakteristike i organizacija sklopova te pridružena im zemljišta u odnosu na naselje, te je učinjena detaljna transkripcija austrijskog katastra iz prve polovice 19. stoljeća s analizom vlasništva i namjene čestica zemlje koja je potvrdila polazišnu hipotezu. Nasljednici Stjepović-Skočibuha su i tada bili većinski vlasnici čestica zgrada i zemlje u Suđurđu.

Ključne riječi: Otok Šipan, naselje Suđurađ, ladanjsko-gospodarski sklopovi obitelji Skočibuha, Tomo i Vice Stjepović-Skočibuha, uobličavanje naselja

Mara Marić, Zavod za mediteranske kulture, Sveučilište u Dubrovniku, Marka Marojice 4, 20000 Dubrovnik, Republika Hrvatska, E-mail adresa: mara.maric@unidu.hr

** Dubravka Mirošević, 20000 Dubrovnik, E-mail adresa: mirosevic.dubravka@gmail.com 


\section{Uvod}

Ladanjsko-gospodarski sklopovi obitelji Stjepović-Skočibuha u naselju Suđurađ na otoku Šipanu ${ }^{1}$, najvećem u elafitskom arhipelagu ${ }^{2}$, jedinstvene su renesansne ladanjske cjeline. Radi se o dva ljetnikovca smještena neposredno jedan pored drugoga koje su sredinom 16. stoljeća sagradili pučani Tomo Stjepović-Skočibuha i njegov sin Vice Stjepović-Skočibuha. Značenje njihovih ljetnikovaca očituje se u veličini i sadržaju sklopova, zbog čega se ubrajaju među najvrjednije, spomenike renesansnoga graditeljskog nasljeđa.

Ovaj rad rezultat je istraživanja provedenog u okviru izrade završnoga rada preddiplomskoga sveučilišnog studija Povijest Jadrana i Mediterana na Sveučilištu u Dubrovniku. ${ }^{3}$ Istraživanje je bilo usmjereno na povijesne, stilske i organizacijske značajke ladanjskih zdanja te utvrđivanje doprinosa obitelji Stjepović-Skočibuha na strukturiranje Suđurđa. Polazišna hipoteza jest da su ladanjski sklopovi te obitelji znatno utjecali na uobličavanje naselja. Njihov centralni položaj u uvali na čijem je središnjem platou u prošlosti bilo brodogradilište, elementi sklopa (kule) koji postaju temeljni orijentiri naselja te poticanje naseljavanja uvale upućuju na to.

Istraživanje ima interdisciplinarni karakter budući da metode rada nisu vezane isključivo za povijesne discipline. Provedeno je opsežno prikupljanje literaturne građe o povijesnim i prostornim značajkama Šipana, Suđurđa te samih ladanjskih sklopova. Na temelju sistematične terenske opservacije analizirane su organizacijske i stilske značajke ladanjskih sklopova s posebnim naglaskom na perivojnim prostorima. Provedena je komparativna analiza tih sklopova u odnosu na ladanjske sklopove na Šipanu te su izdvojene osobitosti cjelina. Na teme-

\footnotetext{
1 Etimologija riječi Šipan nije do kraja razjašnjena jer su mišljenja povjesničara podijeljena. Prema jednima, naziv otoka je slavenskoga podrijetla i dolazi od riječi „župan” (zuppana ili cuppana), a prema drugima dolazi od grčke riječi Gypanon („orlovo gnijezdo”). U literaturi se spominje još i latinski naziv Tauris (Taurida). Tauris se prvi put spominje 47. g. pr. Kr., i to u bitci između Pompejeva pristaše Oktavija i Cezarova sljedbenika Vatinija. U srednjovjekovnoj ispravi iz 1222. šipanski vinogradi nazivaju se vinae Juppanae. Hrvatska inačica riječi Šipan prvi se put javlja u potvrdi iz 1370. godine. Josip Lučić, „Prošlost elafitskog otoka Šipana (do 1300.) godine”, Starohrvatska prosvjeta 3 (1968), br. 10: 94; Josip Lučić, „Građevinski spomenici XIII stoljeća na Šipanu”, Prilozi povijesti umjetnosti u Dalmaciji 13 (1961), br. 1: 78-84; Petar Skok, Slavenstvo i romanstvo na jadranskim otocima (Zagreb: Jadranski institut JAZU, 1950), 234-235.

2 Otok Šipan nalazi se u Dubrovačko-neretvanskoj županiji i pripada skupini Elafitskih otoka, koje je još Plinije Stariji nazvao Elafitima (grč. Elaphites), što u prijevodu znači ,jelen” (èlaphos u jednini), odnosno „zemlja bogata jelenima” (Elaphitides u množini). Elafite čine otoci Olip, Jakljan (Lakjan, Lakljan), Šipan, Lopud, Koločep (Kalamota) i Daksa te otočići i hridi Tajan, Crkvina, Goleč, Kosmeč, Mišnjak, Ruda, Sutmiho, Sv. Andrija, Veliki i Mali Skupio i Greben. Najmanji od otoka je Koločep (Kalamota), a najveći, površine $16 \mathrm{~km}^{2}$, upravo Šipan.

3 Rad naslova „Ladanjsko-gospodarski sklopovi obitelji Stjepović-Skočibuha u Suđurđu na otoku Šipanu” obranjen je 10. srpnja 2020. pod mentorstvom doc. dr. sc. Mare Marić.
} 
lju povijesne kartografije, austrijskoga katastra iz 1837., analizirani su povijesni prostorni odnosi u Suđurđu, pozicija ladanjsko-gospodarskih sklopova obitelji Stjepović-Skočibuha, vlasnički odnosi i namjena zemljišta u naselju.

\section{Položaj i najstarija povijest Suđurđa}

Otok Šipan proteže se od rta Stari brod do rta Prtuša u ukupnoj duljini od 9 km i širini od 2,5 km. ${ }^{4}$ Obala otoka razvedena je i sastoji se od više uvala i uvalica, među kojima veličinom i važnošću prednjače Šipanska Luka smještena na sjeverozapadu te Suđurađ na jugoistoku. ${ }^{5}$ Dva pola otoka povezuje Šipansko polje, koje se proteže u duljini od $4 \mathrm{~km}$ (in campo giupanensi). ${ }^{6}$ Šipansko je polje za naselja na Šipanu, uključujući Suđurađ, u prošlosti bilo životno važan prostor jer je to najplodniji dio otoka, na kojem su i izvorišta žive vode. ${ }^{7}$ Komunikacija koja je povezivala Suđurađ i Šipansku Luku, ali i ostala naselja (smjerovi za Pakljenu na sjevernoj i Prtušu na južnoj strani) $)^{8}$, položena je vrlo promišljeno uz istočni rub Šipanskoga polja da bi se čim više sačuvao prostor za poljoprivrednu djelatnost, nekada temeljnu granu otoka. Ladanjska zdanja po istom se principu smještaju po rubovima polja (zapadni rub) prema renesansnim načelima, prema kojima se njeguje skladan odnos između čovjeka i prirode, tj. izgrađenoga, kultiviranoga i prirodnoga krajolika. ${ }^{9}$

Uvala u kojoj je smješteno naselje Suđurađ prirodno je zaštićena od vjetrova i mora, stoga se od davnina spominje kao vala od pogjate (tal. poggiata - bez vjetra). ${ }^{10}$ Ispred uvale se nalaze šumoviti otočić Ruda ${ }^{11}$ te hridi Plosnavi i Go-

\footnotetext{
Ante Pelivan, „Elafiti: nepoznato otočje”, Ekološki glasnik 6 (1996/1997): 7-19; Aida Cvjetković, Mirisi, boje i orisi otoka Šipana (Dubrovnik: Vlast. nakl., 2003), 9.

5 Najviša je točka otoka (243 m nadmorske visine) Veli (Velji) vrh, a nešto je niži (223 m) Sv. Ilija. Pelivan, „Elafiti: nepoznato otočje”, 17.

6 Lučić, „Prošlost elafitskog otoka Šipana”, 98.

7 Lučić, „Prošlost elafitskog otoka Šipana”, 98.

8 Marija Planić-Lončarić, „Suđurađ i Luka na otoku Šipanu”, Zbornik Dubrovačkog primorja i otoka III (1991): 123; Marija Kraljević, „O naselju Suđurađ na otoku Šipanu”, Zbornik Dubrovačkog primorja i otoka VII (1999): 78.

9 Radovan Ivančević, „Iskustvo renesanse za (bolje) suvremene i buduće ceste”, Ceste i mostovi 41 (1995), br. 9-10: 293.

10 Boro Kamić, „Orsani otoka Šipana”, Naše more 30 (1983), br. 6: 268.

11 Dvije su pretpostavke koje se vežu za naziv otočića. Prema jednoj, ime je dobio po riječi rudnik jer je nekad bio pravi i nepresušni „rudnik” različitih vrsta ribe. Prema drugoj pretpostavci, otok je nazvan prema autohtonoj pasmini ovce dubrovačka ruda, koja je nastala križanjem merino ovnova iz Španjolske i domaće ovce još u 15. stoljeću. Boro Kamić, „Ribarstvo otoka Šipana nekad i sad”, Naše more 29 (1982), br. 6: 270; Boro Mioč et al., „Odlike eksterijera dubrovačke ovce”, u: Knjiga priopćenja sa XXXVIII. znanstvenog skupa hrvatskih agronoma, ur. Tito Žimbrek (Zagreb: Hrvatsko agronomsko društvo, 2003), 491-494.
} 
li. ${ }^{12}$ Zahvaljujući dobrom položaju i prirodnim obilježjima ovaj lokalitet bio je pogodan za izgradnju naselja, a Šipansko polje i uvala za obavljanje gospodarske djelatnosti. ${ }^{13}$

Dubrovačka Republika stekla je Šipan, uz elafitske otoke Koločep i Lopud, između 9. i 10. stoljeća. Potom ih je ustrojila u zasebnu jedinicu poznatu kao Tri Otoka ili Otoci. ${ }^{14} \mathrm{Na}$ čelu Otoka bio je knez (comes ili conte). ${ }^{15}$

O samom naselju Suđurađ prije nego što je otok postao dijelom teritorija Republike malo je toga otkriveno. ${ }^{16}$ Poznato je da Rimljani koloniziraju otok u 2. st. pr. Kr. (kada i ostatak dubrovačkoga područja), na što upućuju brojni arheološki lokaliteti, poput tragova villae rusticae na lokalitetu Fratija ${ }^{17}$, kao i toponimi poput onih uz južni rub Veloga polja, ${ }^{18}$ na područjima Kalandrino, Kapičino, Kala Duha, na Veljem vrhu kod crkvice sv. Petar Stari te na putu od Dola prema Dubravi. ${ }^{19} \mathrm{Na}$ lokalitetu Kala Duha pronađen je najstariji dosad objavljeni fragment, ornament luka u romaničkom stilu. ${ }^{20}$

Naziv naselja Suđurađ (izv. De portu sancti Georgii) romanskoga je podrijetla. ${ }^{21}$ Ime je dobilo prema crkvici sv. Đurđa iz 13. stoljeća koja se nalazi u središtu naselja i jedina je cjelovita sačuvana građevina iz srednjega vijeka. ${ }^{22}$ Najvažnija sakralna građevina iz doba Republike jest crkva sv. Nikole, koja je naslonjena na zid crkve sv. Đurđa. ${ }^{23}$ Ispred obje crkve smještena je luža, odnosno loggia po uzoru na onu gradsku. ${ }^{24}$ Crkva Sv. Duha (1577.) u unutrašnjosti Suđurđa, prema

\footnotetext{
${ }_{12}$ Hridi Plosnavi imale su kamene stupiće koji su služili za vezivanje brodova, pa se uz otok Rudu i ostale hridi smatraju dijelom naselja Suđurađ. Kraljević, „O naselju Suđurađ na otoku Šipanu”, 78.

13 Kraljević, „O naselju Suđurađ na otoku Šipanu”, 78.

14 Vinko Foretić, Povijest Dubrovnika do 1808., sv. 1 (Zagreb: Matica hrvatska, 1980), 123.

15 Foretić, Povijest Dubrovnika do 1808., 123.

16 Kraljević, „O naselju Suđurađ na otoku Šipanu”, 79.

17 Lučić, „Prošlost elafitskog otoka Šipana”, 103.

18 Nada Grujić, „Ladanjsko-gospodarska arhitektura 15. i 16. stoljeća na otoku Šipanu”, Zbornik Dubrovačkog primorja i otoka II (1988): 227.

19 Igor Fisković, „Bilješke o starokršćanskim i ranosrednjovjekovnim spomenicima na otoku Šipanu", Prilozi povijesti umjetnosti u Dalmaciji 18 (1970), br. 1: 5-6.

20 Josip Posedel, „Predromanički spomenici otoka Šipana”, Starohrvatska prosvjeta 3 (1952), br. 2: 125.

${ }^{21}$ Lučić, „Prošlost elafitskog otoka Šipana”, 98.

22 Postojanje crkve spominje se 1285. godine. Kraljević, „O naselju Suđurađ na otoku Šipanu”, 80.

${ }_{23}$ Otok je poznat po brojnim sakralnim objektima (oko 30) sagrađenim u srednjem vijeku, od kojih je danas sačuvano desetak. Važno je spomenuti tri crkve za koje se vjeruje da su primjerci starohrvatskoga graditeljstva. Riječ je o crkvama sv. Petra na Veljem vrhu, sv. Ivana u Šilovu Selu i sv. Mihajla u Pakljenoj. Na otoku su i samostanski posjedi benediktinskoga reda, samostan i crkva sv. Mihajla u Pakljenoj. Planić-Lončarić, „Suđurađ i Luka na otoku Šipanu”, 114; Lučić, „Građevinski spomenici XIII stoljeća na Šipanu", 79.

${ }^{24}$ Samuilo Puhiera, „Srednjovekovne crkve na ostrvu Šipanu kod Dubrovnika”, Starinar NS V-VI (1954/55): 233-234.
} 
Šipanskome polju, monumentalna je građevina izgrađena u renesansno-manirističkom stilu na inicijativu Vice Stjepovića-Skočibuhe, voditelja gradnje. ${ }^{25} \mathrm{Ne}-$ daleko se nalaze župna crkva Sv. Marije od Milosrđa i ostaci benediktinskoga samostana.

Iz naziva naselja De portu sancti Georgii proizlazi da se radilo primarno o lučici, $s$ naglašenim ribarskim karakterom, na što upućuju i brojni orsani i magazini u kojima su se čuvale ribarske mreže, alati i barke. ${ }^{26} \mathrm{Uz}$ obalu postoje ostaci starih kamenih bitvi koje su služile za vezivanje barki i brodova. ${ }^{27}$ Ulovljena riba konzervirala bi se soljenjem ili sušenjem i prevozila barkama u gradsku jezgru zajedno s ostalim poljoprivrednim proizvodima, a ribarske barke često bi se vraćale $s$ građevnim materijalom i drugim potrepštinama. ${ }^{28}$ Ribari su imali svoje mjesto u uvali Suđurađ (tzv. Steralo), ${ }^{29}$ na kojem su se nalazile konstrukcije za prostiranje ribarskih mreža. ${ }^{30}$

Kao i na većini otoka, stanovništvo koje je naselilo Suđurađ prvotno je živjelo u unutrašnjosti, na padinama uokolo polja, u naseljima sakrivenim pogledima $s$ pučine jer je obala tada bila nesigurna za život zbog opasnosti koje su vrebale $s$ mora. ${ }^{31}$ Riječ je o danas najvećim dijelom zapuštenim naseljima Frajgi, Sutuliji, Vonjevu i Šilovu Selu, Odžaku, Budim Dolu, Dolu i Dubravi. ${ }^{32}$ Za vrijeme Republike broj stanovnika ovisio je o epidemijama, osobito „crne smrti” koja je 1348. potresla Europu, a potom o gladi i potresima jer je područje Dubrovnika oduvijek seizmički aktivno. ${ }^{33}$ Živjelo se od obrađivanja zemlje, tj. uzgoja vinove loze budući da se prvotno glavnina privređivanja na otoku temeljila na prodaji vina. ${ }^{34}$ Uz lozu, važne su bile masline i smokve, koje su se sušile. Na otoku je bilo razvijeno i stočarstvo, a uzgajala su se goveda, volovi za oranje, krave, konji, koze i sl.

\footnotetext{
${ }_{25}$ Iznad naselja Suđurađ na putu prema Šipanskoj Luci nalazi se crkva Sv. Duha, koja je sagrađena kao utvrda, što govori da je Vice razmišljao o obrani naselja. O crkvi vidi više u: Frano Kesterčanek, „Renesansni dvorci obitelji Stjepovića-Skočibuhe na Šipanu”, Anali Historijskog instituta JAZU u Dubrovniku VIII-IX (1962): 142-143.

26 Kamić, „Orsani otoka Šipana”, 259-270; Kraljević, „O naselju Suđurađ na otoku Šipanu”, 81.

27 Riječ bitta dolazi iz talijanskoga, a označava stup za vezanje na brodu ili u luci. Kamić, „Orsani otoka Šipana”, 268.

28 Kamić, „Ribarstvo otoka Šipana nekad i sad”, 266.

29 Steralo (śteralo - sušilište za mreže) i u drugim ribarskim naseljima označavalo je mjesto za prostiranje/sušenje mreže. Joško Božanić, „Stil, priča, leksik, svijet tezaurusa usmene predaje komiškog ribara Ivana Vitaljića Gusle", Čakavska rič 38 (2010), br. 1-2: 26.

30 Kraljević, „O naselju Suđurađ na otoku Šipanu”, 81.

31 Kraljević, „O naselju Suđurađ na otoku Šipanu”, 80-81.

32 Cvjetković, Mirisi, boje i orisi otoka Šipana, 9.

${ }_{33}$ Stjepan Krivošić, Stanovništvo Dubrovnika i demografske promjene u prošlosti (Dubrovnik: Zavod za povijesne znanosti JAZU u Dubrovniku, 1990), 35-39.

34 Lučić, „Prošlost elafitskog otoka Šipana”, 150.
} 
Pomorstvo je ipak bilo grana koja je donosila najviše dobiti i razlog zbog kojega je većina stanovništva dobro živjela. ${ }^{35}$

\section{Tomo i Vice Stjepović-Skočibuha}

Gospodarski najvažnije razdoblje Suđurđa bilo je za vrijeme Dubrovačke Republike, odnosno tijekom 16. stoljeća, kada se grade ladanjsko-gospodarski sklopovi obitelji Stjepović-Skočibuha u središnjem dijelu naselja. Gradnja sklopova tih obitelji, uz prateće djelatnosti, prije svega brodogradnju, dala je snažniji impuls gradnji stambenih građevina u uvali.

Skočibuhe su bili jedna od najpoznatijih obitelji građanske klase na dubrovačkom području u tom razdoblju. Obitelj se dijelila u tri ogranka: Stjepović, Krivonosović i Sagrojević. ${ }^{36}$ Većina muškoga dijela obitelji tradicionalno se bavila brodogradnjom, pomorstvom i trgovinom te tako stekla bogatstvo, ali i utjecaj. ${ }^{37}$ Članovi obitelji nerijetko su bili i crkveni poglavari, pravnici i književnici. ${ }^{38}$

Izvornim prezimenom Sagrojevići (tal. Sagri) i nadimkom Krivonosovići, potom Skočibuhe, prvi se put spominju sredinom 15. stoljeća na Šipanu, kada ostvaruju i prve veze s Dubrovnikom. Nisu potpuno razjašnjeni korijeni i podrijetlo obitelji, no vjeruje se da su migrirali iz Bosne i Hercegovine. Prema nekim arhivskim spisima i dokumentima, bilježi se da su na Šipanu bili i prije pada Bosne pod vlast Osmanskoga Carstva 1463. godine. ${ }^{39}$

Pomorci i brodovlasnici Antun i Stijepo Sagrojević-Krivonosovićc ${ }^{40}$ dva su brata koja započinju obiteljski uspon početkom 16. stoljeća na otoku Šipanu. Stijepo je imao tri sina, Frana, Marina i Tomu, koji nasljeđuju dvije kuće, staru očevu i

\footnotetext{
35 Pelivan, „Elafiti: nepoznato otočje”, 18.

${ }_{36}$ Više o podjeli obiteljskoga prezimena vidi u: Zrinka Pešorda Vardić, „Od barkuzija do galijuna: Nekoliko crtica o ulozi pomorstva u usponu dubrovačkoga građanstva u kasnome srednjem i ranome novom vijeku", Povijesni prilozi 33 (2014), br. 47: 168-169.

37 Vrijedi napomenuti da su neki članovi obitelji bili i pripadnici ugledne gradske bratovštine antunina; Tomo i Frano Sagri upisani su 1519., a Tomo Antunov Krivonosović 1533./1534. godine. Jurica Bačić, „Stjepović-Skočibuha (Dubrovačka Republika od konca 15. do pred kraj 16. stoljeća)”, Zbornik Dubrovačkog primorja i otoka III (1991): 161; Pešorda Vardić, „Od barkuzija do galijuna”,169.

38 Frano Kesterčanek, „Tragom jednog Michelangelovog djela u Dubrovniku”, Prilozi povijesti umjetnosti u Dalmaciji 11 (1959), br. 1: 63.

39 Gianluca Masi, „Scoccibucca (Skocibuha) and Faccenda (Facenda), Two Families of Shipowners and Merchants in Ragusa (Dubrovnik) between 16th and 17th Century", u: L'Italia e la frontiera orientale dell'Europa, 1204-1669 = Italy and Europe's Eastern Border, 1204-1669, ur. Iulian Miha Damian et al. (Frankfurt am Main itd.: Peter Lang Verlag, 2012), 259-260; Bačić, „Stjepović-Skočibuha”, 161.

40 U crkvi sv. Nikole u Pakljenoj nalazi se poliptih obitelji Krivonosović iz 16. stoljeća, djelo Francesca da Santa Croce. Ivana Čapeta, „Doprinos djelatnosti radionice Santa Croce”, Peristil: zbornik radova za povijest umjetnosti 51 (2008), br. 1: 159-160.
} 
novu koju grade 1529. u uvali Suđurađ. Od devetero Franove djece najpoznatiji je Nikola Sagrojević, koji je zapovijedao na najvećoj dubrovačkoj navi Sv. Duh i Sv. Marija Loretska i usto napisao dvije knjige maritimne tematike. ${ }^{41}$ Tomin brat Frano Stjepović-Sagrojević na dar je primio sliku flamanske škole Bijeg u Egipat od prijatelja, znamenitoga osmanskog moreplovca Hajredina Barbarosse. ${ }^{42}$ Drugi Tomin brat, Marin Stjepović-Sagrojević, imao je četiri sina, koji su živjeli i radili u Napulju i s kojima su Tomo i njegova obitelj održavali rodbinske i poslovne veze. $^{43}$

Tomo Stjepović zvan Skočibuha, ${ }^{44}$ rođen u Pakljenoj na Šipanu 1484., bio je najpoznatiji među braćom. Nastavlja pomorsko-trgovačku tradiciju obitelji, najprije kao mornar, potom pomorski kapetan, brodograditelj i trgovac. Karijeru je završio kao jedan je od najvećih poduzetnika Dubrovačke Republike u 16. stoljeću. ${ }^{45}$ Uz Napulj, vjeruje se da je posjetio i brojne druge mediteranske luke južne Italije, Sicilije, Francuske, Španjolske itd. Zahvaljujući stečenom znanju i iskustvu postaje pomorski zapovjednik ne samo na brodovima svoje obitelji nego i onima Dubrovačke Republike. Razgranatost poslova, ali i njihova raznolikost vidljiva je u trgovačkim knjigama koje je vlastoručno vodio njegov sin Vice. ${ }^{46}$ Tomo je imao šestero djece sa ženom Vicom: kćer Lukreciju i sinove Stjepana, Ruska, Frana, Marina i Vicu. Stjepan i Frano umiru u dječjoj dobi. Rusko i Vice 1555. na obiteljskom brodu Sv. Katarina na putu za Bliski istok doživljavaju okršaj s gusarima, $\mathrm{u}$ kojem Rusko pogiba zajedno s desetoricom mornara. Marin odlazi k rodbini u Napulj, gdje postaje svećenik. ${ }^{47}$

Tomo stvara i privređuje punih trideset godina (1527. - 1557.). Stečeni prihod ulaže u brodograđevnu djelatnost. U Suđurđu je u središnjem dijelu uvale imao vlastito brodogradilište za popravak starih i gradnju novih brodova. Pored toga bavi se bankarskom djelatnošću, a dio prihoda reinvestira u kupnju zemljišta i

\footnotetext{
${ }^{41}$ Riječ je o knjigama Rasprave o promjenama plime i oseke u zapadnom oceanu (1574.) i Izlaganja o plimi i oseki kod Mesinskoga svjetionika (1580.). Pešorda Vardić, „Od barkuzija do galijuna”, 170.

${ }^{42}$ Hajredin Barbarossa bio je gusar osmanske mornarice i gospodar Alžira. Harao je obalama Sredozemlja, pa tako i Dubrovnika, a jedan od njegovih prijatelja bio je Frano Sagrojević, kojega je najvjerojatnije upoznao na nekoj od Franinih ekspedicija po Sredozemlju, možda baš u Alžiru, Turskoj ili nekoj drugoj zemlji Sredozemlja. Božo Cvjetković, Estetska oceanografija (ljepota mora i obale) (Dubrovnik: Komisijonalna naklada štamparije De Giulli i dr., 1920), 78; Kesterčanek, „Tragom jednog Michelangelovog djela", 63.

${ }^{43}$ Bačić, „Stjepović-Skočibuha”, 162-163.

${ }_{44}$ Smatra se da je nadimak Skočibuha Tomo dobio zbog snalažljivosti u izbjegavanju nedaća na moru i svojih intelektualnih sposobnosti. Robin Harris, Povijest Dubrovnika (Zagreb: Golden marketing Tehnička knjiga, 2003), 194.

45 Kesterčanek, „Renesansni dvorci”, 142.

46 Bačić, „Stjepović-Skočibuha”, 163-167.

47 Bačić, „Stjepović-Skočibuha”, 166-167.
} 
nekretnina. Pokazuje interes i za graditeljsku djelatnost, i to najviše u vrijeme kada gubi sina Frana 1542. godine. ${ }^{48}$

U Dubrovniku se od 15. stoljeća gradnja kuće ili palače smatrala odrazom dobroga socijalnog položaja, pa tako osim vlastele svoja zdanja daju graditi i imućni građani koji se žele profilirati i biti u rangu s vlastelom. ${ }^{49}$ Tomo je pravi primjer bogatoga prosvijećenog pučanina. Osim gospodarsko-ladanjske cjeline u Suđurđu (1529. - 1546.) gradi i druge objekte na cijelom području Dubrovačke Republike, od kojih je među najvažnijima monumentalna palača u Dubrovniku na predjelu Pustijerne (u današnjoj Restićevoj ulici) iz 1553. godine. ${ }^{50}$ Tomo je naručivao slike poznatih slikara; jedan njegov portret radi stonski slikar Krsto Nikolin Antunović, a portret majke naručuje od talijanskoga slikara Bernardina Ricciardija. ${ }^{51}$ Kako je njegov građanski ugled rastao, tako je i društvo koje je posjećivalo njegove ljetnikovce i palače bilo birano i učeno, pa Tomu znameniti dubrovački nadbiskup Lodovico Beccadelli naziva svojim dragim prijateljem. ${ }^{52}$

Tomo Stjepović-Skočibuha umro je 1559. godine. ${ }^{53}$ Oporučno ostavlja svu svoju imovinu sinovima Marinu i Vici s nalogom da njegova žena bude jednako uključena u vođenje gospodarstva te uz napomenu neka se ne prodaje ništa od obiteljske stečevine, kao i uputu za buduće generacije da se imovina prenosi s koljena na koljeno po muškoj liniji. ${ }^{54}$

Kako je Tomin sin Marin bio svećenik, sve pomorsko-trgovačke, brodograđevne i građevinske poslove preuzima sin Vice, rođen 1534. u Suđurđu na Šipanu, gdje provodi djetinjstvo. Vice karijeru u obiteljskom poslovanju započinje kao

48 Tada se s obitelji seli u povijesnu jezgru na Prijeko u kuću prijatelja Frana Bogojevića, u kojoj će živjeti nekoliko godina. Bačić, „Stjepović-Skočibuha”, 167.

49 Nada Grujić, „Reprezentativna stambena arhitektura”, u: Zlatno doba Dubrovnika - XV. i XVI. stoljeće, ur. Vladimir Marković (Zagreb; Dubrovnik: Muzejski prostor Zagreb; Dubrovački muzej, 1987), 66.

50 Istančanost ukusa Tome Stjepovića-Skočibuhe ogledala se u uređenju interijera njegovih palača, koje su bile ukrašene skupocjenim slikama i lijepim komadima namještaja uvezenima iz Italije. Kesterčanek, „Renesansni dvorci”, 142; Bačić, „Stjepović-Skočibuha”, 175.

51 Od slikara Krste Antunovića 1552. naručuje još dvije slike za crkve: oltarnu sliku s pet likova i svojim portretom, za koju je nepoznato gdje je postavljena, i kopiju oltarne pale Marijina uzašašća, koja je sačuvana i nalazi se u Pakljenoj. Bernardino Ricciardi (Padova - Dubrovnik, 1604.), talijanski slikar čiji je rad zabilježen u Zadru, Šibeniku i Dubrovniku, u kojem se ističu oltarna pala s temom Glavosjek sv. Ivana Krstitelja (1566., Zadar), oltarna pala u katedrali Poklonstvo kraljeva (1569., Šibenik) i oltarna pala sv. Jurja u crkvi sv. Jurja (Đurđa) na Pilama u Dubrovniku (1592.). Bačić, „Stjepović-Skočibuha”, 168; Kesterčanek, „Renesansni dvorci”, 143; Ana Šitina, „Opus Bernardina Ricciardija na istočnoj jadranskoj obali", Ars Adriatica 7 (2017): 195-209.

52 Pešorda Vardić, „Od barkuzija do galijuna”, 172.

53 Bačić, „Stjepović-Skočibuha”, 169; Kesterčanek, „Renesansni dvorci”, 142.

54 Veću svotu ostavlja samostanima dominikanaca i franjevaca sa željom da počiva u dominikanskoj crkvi. 
brodski pisar. Potom napreduje do ranga kapetana. Spomenuti okršaj s gusarima 1555., tijekom kojega je izgubio brata Ruska, odredit će njegov životni put podalje od aktivnoga pomorstva i posvećuje se vođenju trgovačkih knjiga na temelju smjernica dobivenih od oca. Nakon Marinove smrti (1561.) Vice postaje jedini nasljednik obiteljskoga bogatstva. ${ }^{55}$

Trgovačku djelatnost Vice je bilježio veoma uredno i precizno, u četiri vlastoručno pisane i vođene računske knjige. ${ }^{56}$

Slijedeći očev primjer, postao je jedan od najistaknutijih privrednika svojega vremena $^{57} \mathrm{u}$ dubrovačkim pomorsko-trgovačkim i bankarskim poslovima, koji su pored Italije i Balkana obuhvaćali prostore Bugarske, Turske, južne Francuske i Španjolske. ${ }^{58}$ Bio je suvlasnik tvornice sukna u Gradu, posjedovao trgovačka poduzeća u Sofiji i Napulju, a na Šipanu i Koločepu vinograde i maslinike o kojima se osobno brinuo. ${ }^{59}$ Vice je 1585 . zabilježio i vrijednost svoje imovine, koja je procijenjena na 77.284 dukata. $^{60}$

Godine 1556. oženio se Pavlom Paskojević, s kojom je imao desetero djece. ${ }^{61}$

Marljivim radom i kontinuiranim mudrim investiranjem Vici je rastao ugled, pa su mu dubrovačke vlasti ponudile status plemića ,jer Republici b(i)jaše poklonio znatan iznos". ${ }^{62}$ Naslov je odbio jer nije bio prenosiv, dakle vrijedio je samo za njega, no ne i za njegove potomke. ${ }^{63}$ Ipak, Skočibuhe su na prikladan način izrazili svoj status izabravši za obiteljski amblem lik božice Fortune (sreće) Occassio, svojevrsni grb (slika 1). ${ }^{64}$

\footnotetext{
55 Bačić, „Stjepović-Skočibuha”, 178-179.

56 Knjige su bile označene slovima od A do D, od kojih su sačuvane C i D, odnosno treća i četvrta knjiga, u kojima se bilježio dnevni dohodak, a Vice je u njih povremeno zapisivao i neke događaje iz svojega života. Masi, „Scoccibucca (Skocibuha) and Faccenda (Facenda)”, 267; Hrvatska - Državni arhiv u Dubrovniku, Dubrovnik - 63 - Poslovni dokumenti iz privatnih arhiva (Privata), sv. 32 i 32 a, Računske knjige Vice Skočibuhe.

57 Spekulira se da je na Vicinu umješnost u trgovanju i vođenju poslova utjecala knjiga Benedikta Kotruljevića O trgovini i savršenom trgovcu, koja je napisana 1458., a tiskana 1573. u Veneciji. Bačić, „Stjepović-Skočibuha”, 177-178.

58 Josip Luetić, Pomorci i jedrenjaci Republike Dubrovačke (Zagreb: Nakladni zavod Matice hrvatske, 1984), 97-98.

59 Kesterčanek, „Renesansni dvorci”, 143.

60 Masi, „Scoccibucca (Skocibuha) and Faccenda (Facenda)”, 267-268.

${ }^{61}$ Imao je dvije kćeri, Mariju i Franicu, i osam sinova, od kojih su četiri rano umrla. Tomo, Marin, Stijepo i Frano nadživjeli su oca. Kesterčanek, „Renesansni dvorci”, 144.

${ }^{62}$ Serafino Razzi, Povijest Dubrovnika (Dubrovnik: Matica hrvatska, Ogranak Dubrovnik, 2011), 186.

${ }^{63}$ Bačić, „Stjepović-Skočibuha”, 179; Razzi, Povijest Dubrovnika, 186.

${ }^{64}$ Fortuna je često bila prikazivana kao gola žena koja stoji ili jaše dupina pridržavajući se pritom za jedro. Prema mitologiji, Fortuna zaziva sreću i pozitivnu energiju, a u svijetu pomorstva bila je zaštitni znak trgovaca. Prikaz na amblemu može se tumačiti i kao Arion koji jaše na leđima dupina kao
} 


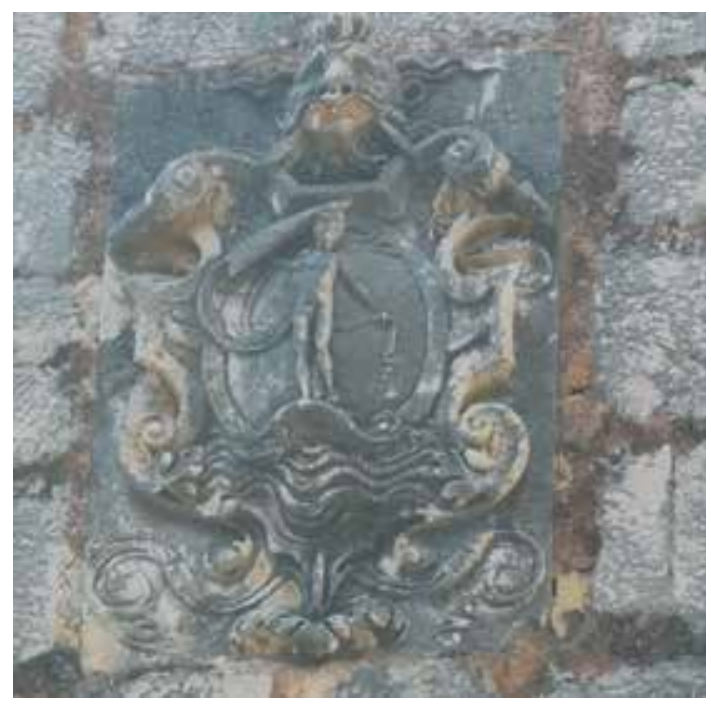

Slika 1. Grb iznad portala ulaznih vrata ladanjske kuće Vice Stjepovića-Skočibuhe (foto: Dubravka Mirošević)

Vice od oca nasljeđuje sklonost prema graditeljstvu i umjetnosti te se izobražava gledajući i putujući svijetom, zbog čega je svoje kuće i palače kontinuirano dorađivao i dotjerivao. To je vidljivo na primjeru palače u Pustijerni, koju daje decentno i primjereno doraditi. ${ }^{65} \mathrm{Od}$ zdanja koja je dao izgraditi ističu se ladanjski sklop u Suđurđu (1561.) i raskošni ljetnikovac na predjelu Boninova „Između tri crkve" (1574.), koji se atribuira talijanskim graditeljima. ${ }^{66}$ Daje izgraditi kapelu sv. Tome ${ }^{67}$ pokraj svojega zdanja u Suđurđu ${ }^{68}$ i sakristiju Sv. Marije u Pakljenoj,

moguća poveznica s Vicinim spašavanjem od gusarskoga napada na brodu Sv. Katarina. Arion (grčki

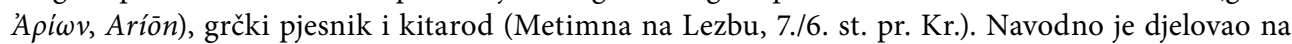
dvoru korintskoga tiranina Perijandra. Djela mu nisu sačuvana. Prema predaji, tvorac je ditiramba, korske pjesme posvećene Dionizu. Legenda pripovijeda da su ga na putu za Korint gramzivi mornari pokušali ubiti bacivši ga s broda, ali mu je život spasio dupin, očaran zvucima njegove pjesme. Milan Pelc, „Fortuna s 'grba' Skočibuha - identitet i mentalitet trgovaca u renesansnom Dubrovniku”, u: Metamorfoze mita. Mitologija u umjetnosti od srednjega vijeka do moderne (Zbornik radova znanstvenog skupa „Dani Cvita Fiskovića” održanog 2010. godine), ur. Dino Milinović i Joško Belamarić (Zagreb: Odsjek za povijest umjetnosti Filozofskog fakulteta Sveučilišta u Zagrebu, 2012), 67-69; „Arion”, Hrvatska enciklopedija, mrežno izdanje (Leksikografski zavod „Miroslav Krleža”), pristup ostvaren 20. 5. 2020., https://www.enciklopedija.hr/natuknica.aspx?id=3803.

65 Bačić, „Stjepović-Skočibuha”, 179.

${ }_{66}$ Razzi piše da je ljetnikovac bio „kraljevske veličajnosti”. Razzi, Povijest Dubrovnika, 186; Nada Grujić, „Ljetnikovac Vice Stjepovića-Skočibuhe kod Tri crkve u Dubrovniku: Ishodište arhitektonskog tipa”, Radovi Instituta za povijest umjetnosti 12-13 (1988): 222; Kesterčanek, „Renesansni dvorci”, 142.

67 Kesterčanek, „Renesansni dvorci”, 151.

${ }_{68}$ Vice je, kao bogati pučanin, očito dobro raspolagao novcem jer je planirane preinake i gradnje poput raskošnoga ladanjskog zdanja u Suđurđu uspio i cjelovito dovršiti. Naime, mnogi su plemići zbog po- 
koje se ubrajaju u dragocjene spomenike 16 . stoljeća ${ }^{69}$ Vice je naručivao slike poznatih slikara. Najpoznatija je pala Silazak Sv. Duha, na kojoj je i Vicin portret, čuvenoga talijanskoga renesansnog slikara Giorgia Vasarija. ${ }^{70}$ Pala se čuva u dominikanskom samostanu u Dubrovniku (slika 2). ${ }^{71}$

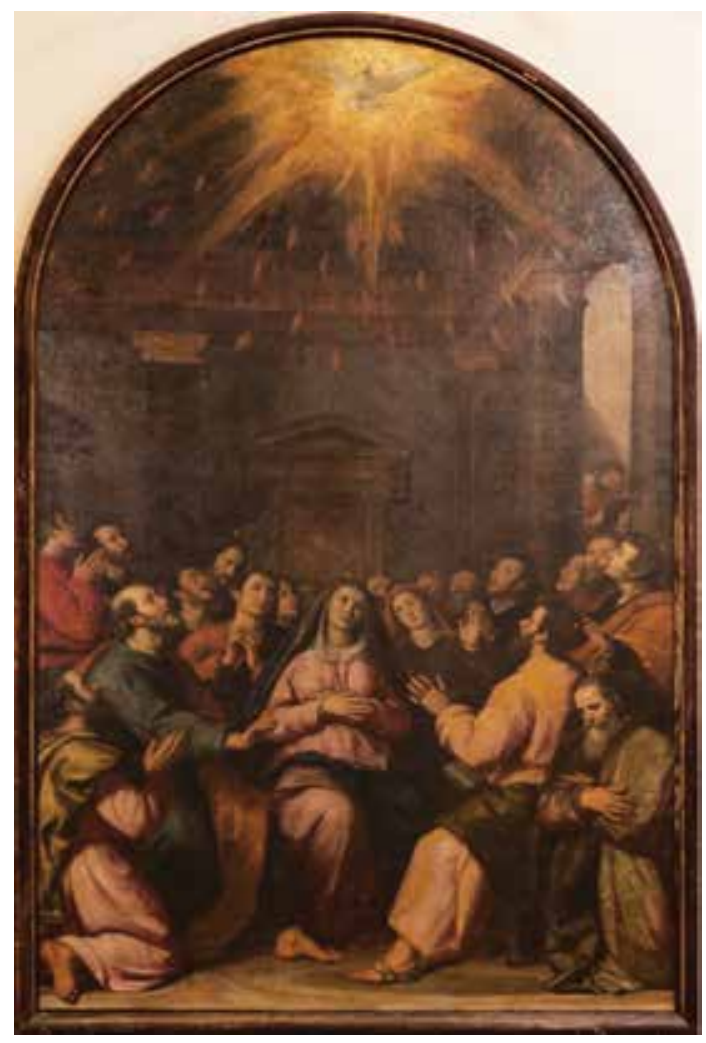

Slika 2. Silazak Sv. Duha u dominikanskom samostanu u Dubrovniku (foto: Boris Jović)

manjkanja sredstava, lošega planiranja ili jednostavno lošega raspolaganja novcem svoja zdanja ostavljali nedovršenima. Primjerice, u Rastićevu ljetnikovcu na Konaliću nedostaje kapelica. Poznato je da se Klement Gučetić kontinuirano zaduživao i prodavao djedovinu da bi dovršio svoju rezidenciju na predjelu Delubia u Rijeci dubrovačkoj, pa tako kapelica i paviljon nisu nikada izgrađeni. Slavica Stojan, Ombla, vile i vilani. Povijest svakodnevnice u ljetnikovcima Rijeke dubrovačke (15. do 19. st.) (Zagreb; Dubrovnik: Hrvatska akademija znanosti i umjetnosti, Zavod za povijesne znanosti u Dubrovniku, 2018).

69 Kesterčanek, „Renesansni dvorci”, 142-143.

${ }^{70}$ Giorgio Vasari (Arezzo, 1511. - Firenca, 1574.), talijanski slikar, graditelj i pisac o umjetnosti. U brojnim talijanskim gradovima radio je zidne slike, portrete, biblijske i alegorijske kompozicije, a gradio je i za Cosima I. Medicija. „Vasari, Giorgio”, Hrvatska enciklopedija, mrežno izdanje (Leksikografski zavod „Miroslav Krleža”), pristup ostvaren 21. 5. 2020., https://www.enciklopedija.hr/natuknica. aspx?id=63953.

${ }^{71}$ Ostale slike naručivao je poput svojega oca od poznatih slikara Krste Antunovića i Bernardina Ricciardija. Kesterčanek, „Renesansni dvorci”, 143; Kruno Prijatelj, „O autoru Skočibuhine pale u dubrovačkih dominikanaca", Peristil: zbornik radova za povijest umjetnosti 6-7 (1963), br. 1: 67. 
Vice 17. prosinca 1588. sastavlja oporuku, a umire 26. prosinca iste godine. Kako njegova djeca nisu imala muških potomaka, obiteljsko prezime prestaje postojati u 17. stoljeću. ${ }^{72}$

O statusu Vice Skočibuhe u to vrijeme svjedoči tekst poznatoga talijanskog dominikanca Serafina Razzija, koji u svojoj Povijesti Dubrovnika navodi: „Otok Šipan, poznat je (...) koliko zbog plemenitosti, izvrsnosti duha vrijednih ljudi koje oduvijek daje gradu Dubrovniku, kao što su u naše vrijeme Skočibuha, Sagroević i drugi. (...) Prije gospar Vice Skočibuha, rođen na ovome otoku, čovjek ugledna imena, vlasnik više brodova, graditelj palača, kapela i crkava te, što je najvažnije, veliki dobročinitelj, u dobi od 54 godine preseli se na bolji svijet. (...) Odavna se nije vidjelo tako mnoštvo naroda kao na pogrebu ovoga velikoga dobročinitelja. Oplakivahu ga svi siromasi grada i okolice, a mora da su se jako ožalostili jadni robovi njegovi sugrađani koji se nalaze u Berberiji, jer bi on svake godine otkupio nekoga od njih (...)."73

U najbližem srodstvu s obitelji Stjepović-Skočibuha bila je obitelj Fačenda jer se Franica, kći Vice Stjepovića-Skočibuhe, udala za Dubrovčanina Ivana Fačendu. Smrću posljednjega člana obitelji Stjepović-Skočibuha 1644. imovina prelazi u ruke obitelji Fačenda, potom u vlasništvo obitelji Zuzorić, a nakon toga obitelji Bizzaro. ${ }^{74}$ Nikoleta Gučetić r. Fačenda (1811. - 1863. ${ }^{75}$ i preudana Lichtenberg nasljeđuje 1863. jedno od zdanja u Suđurđu. Nakon njezine smrti ladanjski sklop nasljeđuje muž joj Fridrik barun Lichtenberg (do 1877.). Tijekom 19. stoljeća Tomino zdanje kupuje Nikola Ogrizić, ${ }^{76}$ potom prelazi u vlasništvo Curića, a danas ga posjeduje obitelj Muratti. ${ }^{77}$

\footnotetext{
72 Bačić, „Stjepović-Skočibuha”, 183.

73 Razzi, Povijest Dubrovnika, 185.

74 Zbog toga su plemići Bizzaro posljednji vlasnici Tomine palače u Pustijerni iz 1553. godine.

75 Nikoleta Fačenda (Facenda) rođena je 17. rujna 1811. u Dubrovniku, a preminula 6. travnja 1863. u Dubrovniku (Pile). Bila je udana za Luku Gučetića (Gozze), a nakon njegove smrti preudala se za Fridrika-Augusta Ludwigova de Lichtenberga. Nenad Vekarić, Vlastela grada Dubrovnika. Korijeni, struktura i razvoj dubrovačkog plemstva, sv. 8 (Zagreb; Dubrovnik: Hrvatska akademija znanosti i umjetnosti, Zavod za povijesne znanosti u Dubrovniku, 2017), 166; Kesterčanek, „Tragom jednog Michelangelovog djela", 68.

76 Rod Ogrizića je iz Suđurđa (Sutulija), a onamo su se doselili u 16. stoljeću iz Bara u Crnoj Gori. Nikola Antunov rođen je 17. svibnja 1772. u Suđurđu, gdje je i preminuo 19. siječnja 1862. godine. Vidi: Genealoška baza podataka Nenada Vekarića.

77 Kesterčanek, „Tragom jednog Michelangelovog djela”, 64.
} 


\section{Ljetnikovci obitelji Stjepović-Skočibuha}

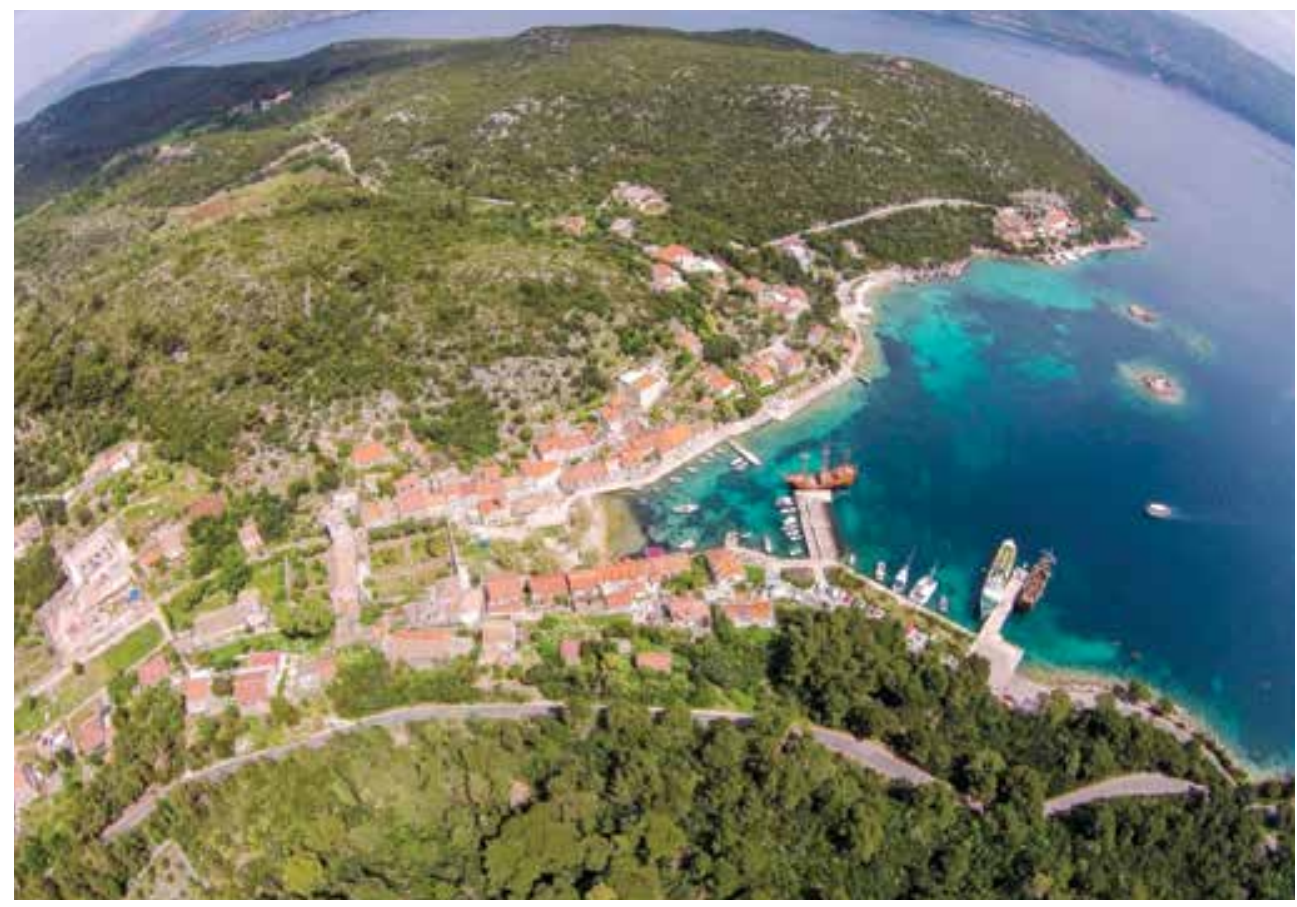

Slika 3. Uvala Suđurađ i ladanjsko-gospodarski sklopovi Tome i Vice Stjepovića-Skočibuhe (foto: Šime Fabris)

Otok Šipan zbog svojih je prirodnih obilježja, u prvom redu velikoga zaštićenoga plodnoga Šipanskog polja, bio idealno mjesto za ladanje, ali i ubiranje ljetine. Zabilježeno je čak 39 ljetnikovaca koje je izgradila dubrovačka vlastela, bogati pučani, ali i stranci koji su stanovali na otoku u 15. i 16. stoljeću, u zlatno doba Dubrovačke Republike. ${ }^{78}$

Po rubovima Šipanskoga polja ostaci su dvadesetak gospodarskih zgrada i zdanja. Na području Giardin ispod brda Sutulija smješten je ladanjski sklop obitelji Sorkočević, ${ }^{79}$ a kod lokaliteta Biskupovo nalazi se ladanjsko-gospodarska cjelina Lodovica Beccadellija, poznatoga talijanskog pisca i pjesnika, u to vrijeme i dubrovačkoga nadbiskupa. ${ }^{80}$

78 Deša Karamehmedović, „Prostorna i funkcionalna klasifikacija dubrovačke ladanjske arhitekture: doprinos društvenom vrednovanju", Anali Zavoda za povijesne znanosti Hrvatske akademije znanosti i umjetnosti u Dubrovniku 53/2 (2015): 466; Grujić, „Ladanjsko-gospodarska arhitektura”, 225.

79 Grujić, „Ladanjsko-gospodarska arhitektura”, 270.

${ }^{80}$ U ljetnikovcu se nalazi friz na kojem je oslikano nekoliko portreta, a jedan prikazuje Michelangela. Slobodan Prosperov Novak, Dubrovnik iznova (Zagreb: Sveučilišna naklada Liber; Međunarodni slavistički centar SRH, 1987), 167. 
Veći broj ljetnikovaca nalazi se u naselju Šipanska Luka, koje je zbog smještaja u dubokoj zaštićenoj uvali okruženoj padinama bilo primjerenije za njihovu izgradnju. ${ }^{81}$ Neposredno iznad Šipanske Luke, s pogledom na Mljetski kanal, nalazi se Knežev dvor izgrađen 1450. u gotičko-renesansnom stilu.

U Suđurđu, dublje unutar naselja, prema Polju, nalaze se ljetnikovci plemićkih obitelji Getaldić (1516.) i Ranjina te građanske obitelji Cvjetkovićc. ${ }^{82}$ I obitelj Kaboga podignula je u 16. stoljeću ljetnu rezidenciju u blizini, na otočiću Rudi ispred uvale Suđurađ. ${ }^{83}$

Ljetnikovci obitelji Skočibuha, posebno Vicin, složenošću i veličinom nadmašili su ipak sve ostale sagrađene do tada na Šipanu (slika 3).

Područje uvale Suđurađ koje Tomo kupuje 1528., neposredno u blizini Getaldićeva ljetnikovca (1516.), nekadašnji je posjed vlastelina Pavla Gučetića ${ }^{84} \mathrm{Na}$ tom zemljištu krajem 1529. Tomo daje sagraditi ljetnikovac, koji dovršava 1546., kako stoji uklesano na pročelju kuće (slika 4). ${ }^{85}$

Tomino zdanje smješteno je u unutrašnjosti Suđurđa, na zapadnoj strani udoline. Važno je primijetiti da je sklop orijentiran pročeljima građevina prema glavnoj otočnoj komunikaciji - Polju, kao i Getaldićev ljetnikovac. Dakle, sklop ne korespondira s priobalnim dijelom naselja, što upućuje na zaključak da uzobalni dio naselja Suđurađ u to vrijeme nije bio do kraja strukturiran.

Tomin sklop ${ }^{86}$ objedinjuje dva tipa obitavanja u jednome - obradu zemlje i ladanjski boravak, zbog toga je i više različitih objekata u jednoj cjelini: ladanjska

\footnotetext{
${ }_{81}$ Tu su ljetnikovci mnogih dubrovačkih vlasteoskih obitelji, među kojima i oni Sorkočevića, Lukarevića i ugledne građanske obitelji Altesti. Grujić, „Ladanjsko-gospodarska arhitektura”, 231-232; Patricija Veramenta, „Grobnica obitelji Federika Glavića na Boninovu”, Anali Zavoda za povijesne znanosti Hrvatske akademije znanosti i umjetnosti u Dubrovniku 50 (2012): 341.

82 Kraljević, „O naselju Suđurađ na otoku Šipanu”, 86.

${ }^{83}$ Kaboge su ondje izgradili ljetnu rezidenciju zajedno s crkvom Sv. Marije, a poslije su u tom kompleksu boravili augustinci, koje su zamijenili dominikanci. Branko Nadilo, „Razvitak hrvatskih otoka. Otoci uokolo Dubrovnika", Građevinar 52 (2000), br. 10: 617-630.

${ }^{84}$ Iduće godine odlučuje se na kupnju ostatka Gučetićeve zemlje, koja je bila u najmu pučana Mihovila (ili Mihoća) Matkovića i Nikole Milatovića. Navedeni iznos za tu zemlju isplaćuje državnim blagajnicima i kuratoru crkve sv. Đurđa. Bruno Šišić, „Renesansni vrtovi u Suđurđu na otoku Šipanu”, u: Simpozij Povijesni vrtovi, perivoji i parkovi primorske Hrvatske, ur. Dražen Grgurević (Split: Franjo Kluz d.d. Omiš, 1998), 155; Bačić, „Stjepović-Skočibuha”, 171.

${ }_{85}$ U ljetnikovac se po završetku izgradnje useljava njegov brat Frano sa svojom obitelji. Braća Sagrojević-Stjepović 1537. rade diobu naslijeđenih i stečenih dobara, kojom Tomi pripada ljetnikovac s obližnjim zemljištem. Tomo daje dopuštenje Frani da živi u kući još šest godina, no ta odluka postat će razlog razmirica između njih dvojice te će se prenijeti na njihovu djecu koja nasljeđuju imovinu. Bačić, „Stjepović-Skočibuha”, 173; Kesterčanek, „Renesansni dvorci”, 145-146.

${ }_{86}$ Zdanje ima oblik asimetričnoga četverokuta, a zauzima $2100 \mathrm{~m}^{2}$, pri čemu je sjeverna strana najduža, zapadna najkraća, a južna i istočna su ravne te jedna prema drugoj gotovo pravocrtno postavljene. Šišić, „Renesansni vrtovi u Suđurđu”, 156.
} 


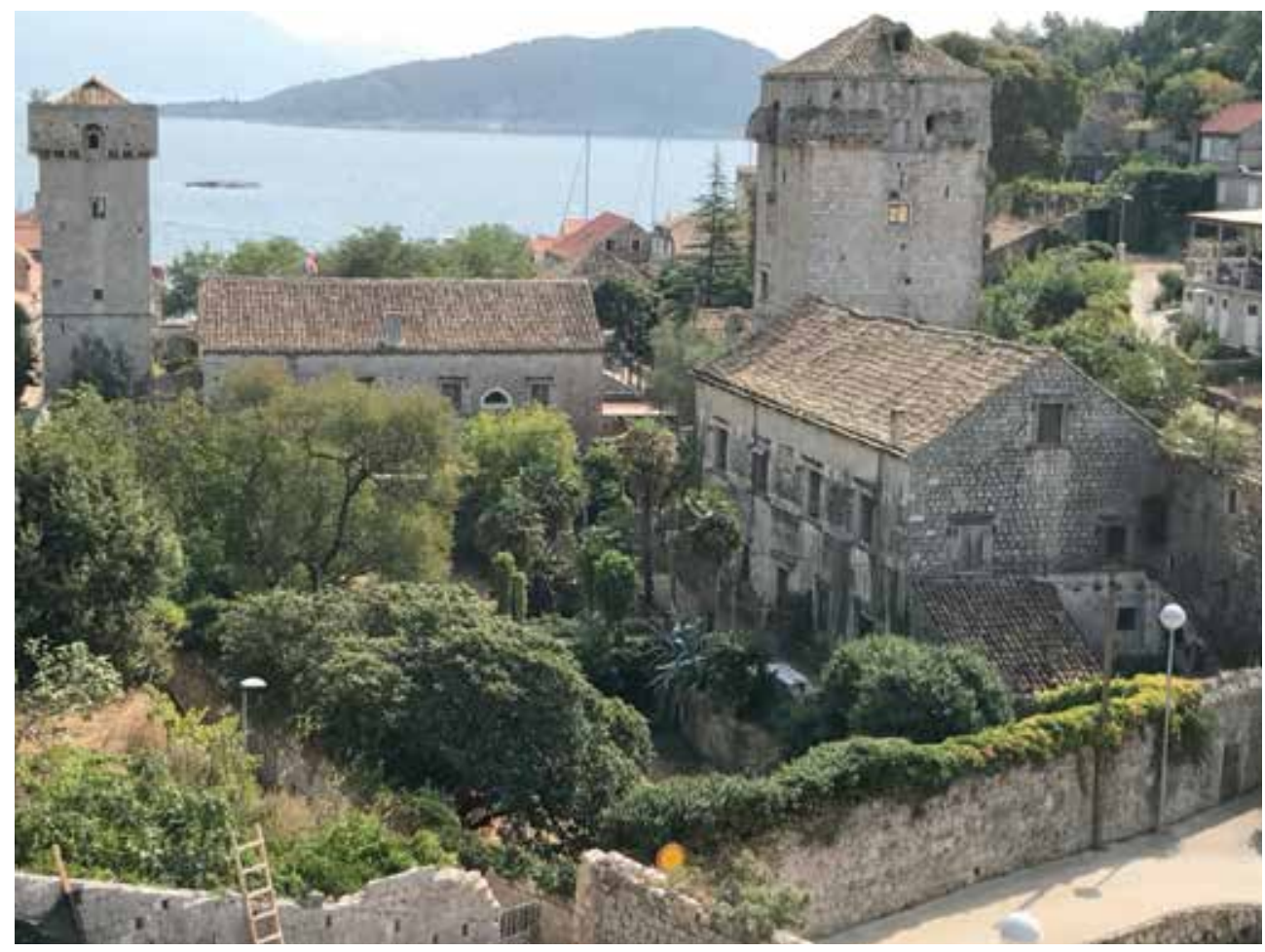

Slika 4. Pogled na Tomin ladanjsko-gospodarski sklop (foto: Mara Marić)

kuća, gospodarske prostorije, kula s cisternom, perivoj s terasama i most. ${ }^{87}$ Kuća $\mathrm{s}$ jasnim odlikama renesansnoga stila ${ }^{88}$ zapadnim je pročeljem do razine potkrovlja ugrađena u teren. Zbog te prostorne uvjetovanosti kuća je postavljena 3 $\mathrm{m}$ iznad perivoja, $\mathrm{i}$ to tako da je glavni portal spojen mostom $\mathrm{s}$ ulaznim vratima zdanja u sjevernom ogradnom zidu. Izdignuta šetnica, zapravo most s dva lučna otvora, služio je za odvodnju u vrijeme velikih kiša da voda iz Šipanskoga polja ne bi plavila zdanje. Zbog toga je izvjesno da renesansni perivoj Tomina ljetnikovca, jedan od rijetkih koji su građeni u prvoj polovini 16. stoljeća, a koji je sačuvan u izvornim gabaritima, nije bio reprezentativan poput Vicina. ${ }^{89} \mathrm{Tu}$ funkciju reprezentativnosti preuzelo je predvorje kuće, na čijem su rubnom zidu uzidane

87 Grujić, „Ladanjsko-gospodarska arhitektura”, 231, 236.

${ }^{88}$ Da je građena u renesansnom stilu može se vidjeti i po pročelju koje ima ujednačen raspored većih i pravilnih otvora. Prozore prizemlja ladanjske kuće iznad njihova gornjega dijela krasi dekorativni element denta, a na prozorima prvoga kata kuće s obje strane po gornjem i donjem rubu stoje kamene uši (klesane kamene prošupljene konzole), koje su nekada bile koristan element za potrebe ukućana. Naime, kroz kamene uši umetnula bi se drvena motka na koju bi se stavljalo sušiti rublje odnosno tkanina da bi se ukućani zaštitili od vanjskih pogleda, ali i vrućine u ljetnim mjesecima. Grujić, „Ladanjsko-gospodarska arhitektura", 262.

89 Tomin perivoj zauzima 77 \% površine sklopa. Šišić, „Renesansni vrtovi u Suđurđu”, 156. 
kamene kupe s naslonima za sjedenje obložene opekom. Ondje je postavljen i stupored za pergolu ${ }^{90}$ te kameni pitari, fino klesani u obliku pehara i sa stiliziranim lisnim vijencem, namijenjeni dekorativnom bilju. ${ }^{91}$

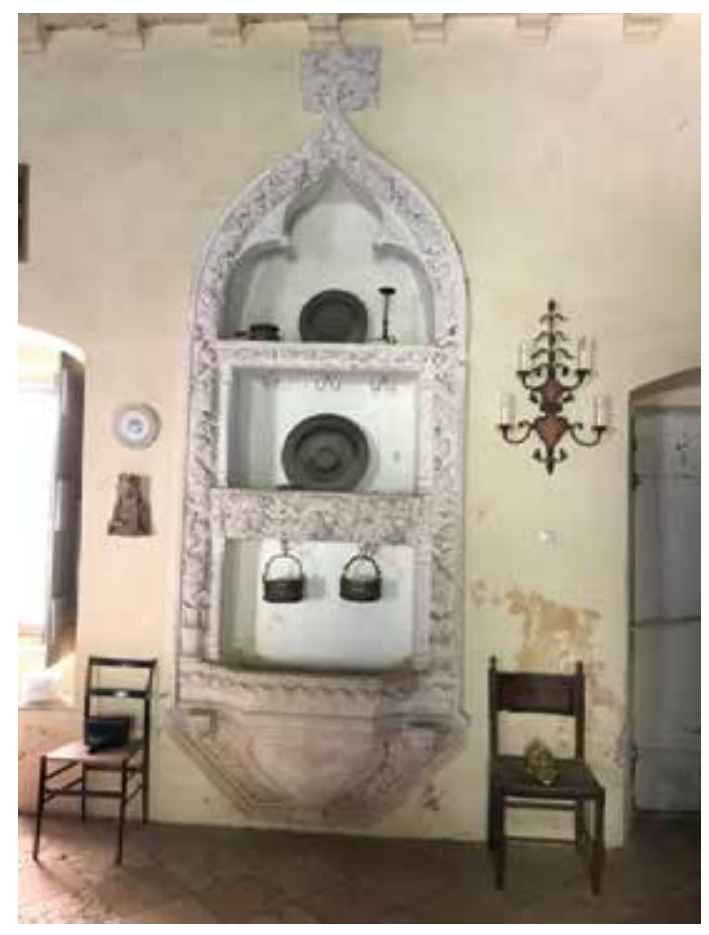

Slika 5. Gotičko pilo u ljetnikovcu Tome Stjepovića-Skočibuhe (foto: Mara Marić)

Interijer kuće uobičajen je za to vrijeme: u prizemlju je središnja prostorija s nekoliko malih pomoćnih prostorija, a na katu u sredini glavna prostorija saloča s dvije manje bočne prostorije (spavaće sobe). ${ }^{92}$ Posebnost tlocrta prostorija je koja se nalazi do saloče, za koju se smatra da je služila kao „poslovni” prostor. ${ }^{93} \mathrm{Da}$ se

90 Pergola (odrina) važan je element dubrovačkoga renesansnog perivoja budući da se nalazi iznad šetnica koje predstavljaju kralježnicu vrta i tako povezuje sve sadržaje ladanjskoga zdanja. Služila je kao zaštita od sunca i omogućavala ugodnu šetnju perivojem. Bruno Šišić, Dubrovački renesansni vrt: nastajanje i oblikovna obilježja (Dubrovnik: Hrvatska akademija znanosti i umjetnosti, Zavod za povijesne znanosti u Dubrovniku, 1991), 67-68.

91 Šišić, Dubrovački renesansni vrt: nastajanje i oblikovna obilježja, 74.

92 Takav tlocrt unutrašnjosti bio je specifičan za ladanjske kuće na tadašnjem dubrovačkom području. Venecijanska gotovo podrugljiva uzrečica Quatro stanze, un salon, z'e la casa d'un Schiavon potvrđuje da se na našim prostorima čvrsto držalo takva rasporeda prostorija u ladanjskoj kući. Nada Grujić, Ladanjska arhitektura dubrovačkog područja (Zagreb: Institut za povijest umjetnosti Sveučilišta; Nakladni zavod Matice hrvatske, 1991), 78; Bačić, „Stjepović-Skočibuha”, 174-175.

93 Nije spojena ni sa jednom prostorijom u kući, nego ima ulaz iz vrta kroz vlastita vrata uokvirena portalom. Grujić, Ladanjska arhitektura dubrovačkog područja, 187. 
radilo o kući bogatoga brodovlasnika i trgovca vidljivo je iz još jednoga detalja interijera. Naime, kuću krasi gotički umivaonik s bogato skulptiranim reljefnim rubovima koji se proteže od poda do potkrovlja te se smatra jednim od najljepših primjeraka na dubrovačkom području (slika 5). ${ }^{94}$

Razdoblje nakon Tomine smrti 1559. bilo je burno i opasno zbog učestalijih pljački i napada gusara na dominikance koji su imali kuću i crkvu na obližnjem otočiću Rudi, a osim njih tuda su harali i Osmanlije. ${ }^{95}$ Zbog toga se Vice, u trenutku kada nasljeđuje očevu imovinu, odlučuje na gradnju obrambene kule uz istočni zid kuće (1569.), unutar očeva ljetnikovca.

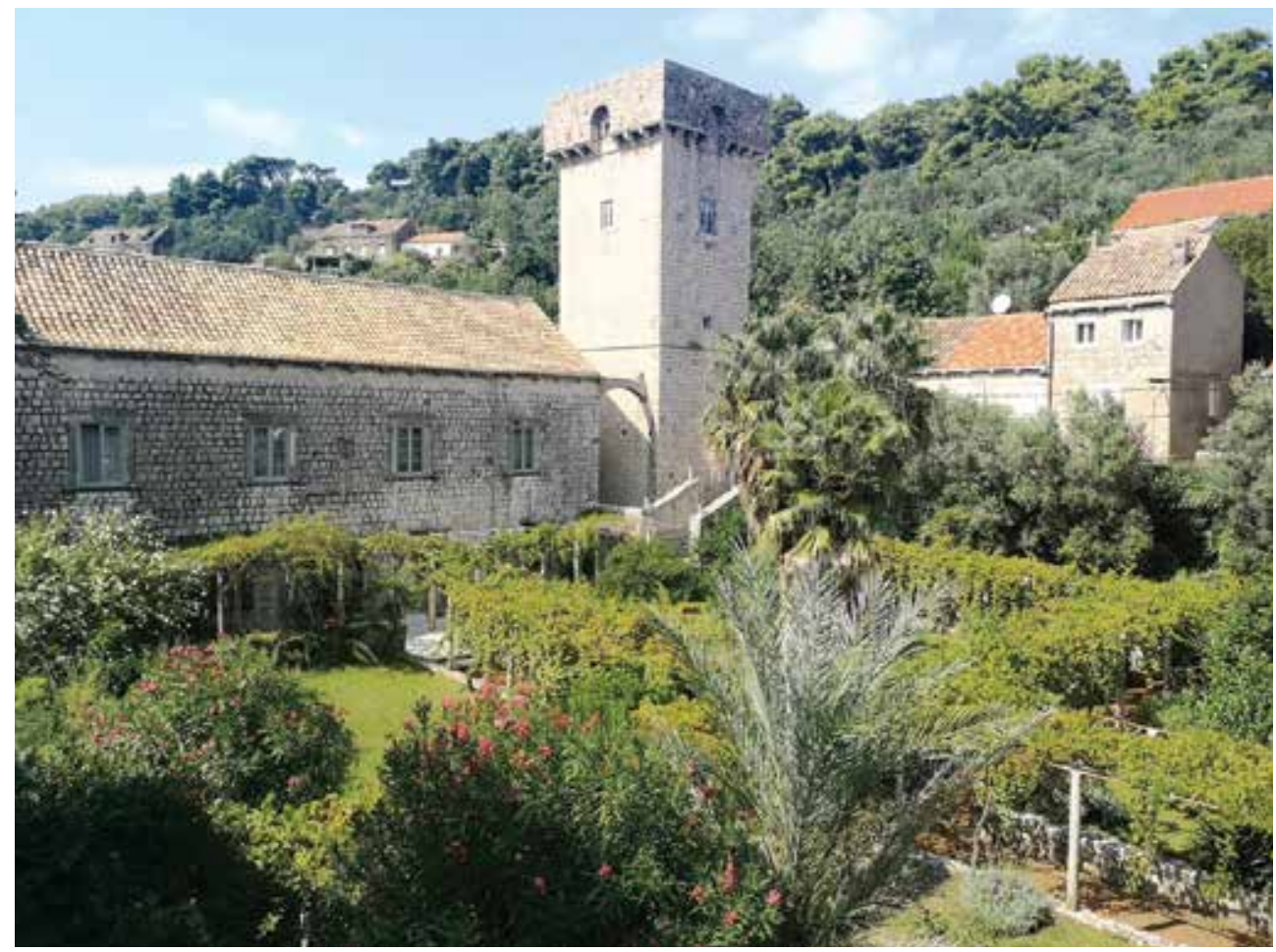

Slika 6. Ladanjska kuća i prednji perivoj - pogled s terase (foto: Dubravka Mirošević)

U ladanjskim zdanjima kule se javljaju rijetko. Najčešće su se gradile na otocima izloženim stalnoj opasnosti s mora i na udaljenijim područjima koja nisu imala tako blisku komunikaciju s gradom. ${ }^{96}$ Kula se ističe visinom, a krasi ju lijepo krunište, niski krov i prozori-puškarnice. Unutar kule ugrađena je cisterna u kojoj se

\footnotetext{
${ }^{94}$ Kesterčanek, „Renesansni dvorci”, 146.

95 Kesterčanek, „Renesansni dvorci”, 146.

${ }_{96}$ Nada Grujić, Prostori dubrovačke ladanjske arhitekture (Zagreb: Razred za likovne umjetnosti JAZU, 1982), 20-21.
} 
prikupljala kišnica s krova, pa se u njoj moglo boraviti tijekom dužega vremena opsade. Pri vrhu kule stoji uzidani obiteljski grb s karakterističnim likom Fortune. No Vice ne gradi kulu samo zbog zaštite svoje obitelji. Ona je bila u funkciji promatračnice, ali i pribježišta i zaštite cijeloga naselja. Izgradnjom kule Tomino zdanje poprima svoj konačni izgled.

Vice 1561. daje sagraditi svoj ladanjski sklop neposredno uz očevo zdanje, a njegov izgled zaokružuje šesnaest godina poslije, kada 1577. daje sagraditi posljednji element - obrambenu kulu (slika 6). ${ }^{97}$

Osim što je mnogo većih dimenzija ${ }^{98}$, Vicina rezidencija bila je bitno raskošnija od očeve, no za ovaj pregled posebno je važan položaj i organizacija samoga sklopa. Za razliku od očeva i Getaldićeva, Vicin je ljetnikovac smješten u središnjem dijelu uvale, neposredno uz nekadašnji škar, i sasvim orijentiran prema moru, vizurama s mora. Glavni ulaz u kompleks upravo je na južnoj strani ogradnoga zida okrenutog moru, a sporedni na istočnoj strani prema putu u Polje.

Da bi takva pozicija, koja je unijela novu kvalitetu u obitavanje na ladanju, bila održiva, Vice je morao dodatno osigurati sklop, tj. čitavu uvalu. Gradi kulu u očevu ljetnikovcu (1569.), zatim unutar vlastitoga zdanja (1577.), a iste godine gradi se i crkva-utvrda Sv. Duha, čiju gradnju inicira upravo Vice. ${ }^{99}$ I pročelni obrambeni zid Vicina zdanja krasi zupčasto krunište, što doprinosi fortifikacijskom karakteru sklopa. K tome Vice naseljava uvalu stanovništvom, daje graditi kuće te u okruženju svojega ljetnikovca prodaje zemljište da bi privukao što više stanovnika s ciljem osiguravanja potrebne radne snage, ali i da bi stanovništvo moglo braniti područje. ${ }^{100}$

U idućim stoljećima elementi fortifikacije koji se grade na Vicin poticaj, i na stvarnoj i na simboličnoj razini, postali su temeljni orijentiri naselja. To dočarava i ilustrirani ormar u Tominu ljetnikovcu s početka 19. stoljeća: prikazan je dolazak Osmanlija i Francuza na otok i susret s njegovim stanovnicima te u pozadini ljetnikovci s utvrdama koji su činili važan dio obrane naselja Suđurađ. Kule su imale i psihološki učinak gledano s mora, pojačavale su dojam „snage” mjesta (slike 7,8,9 i 10).

\footnotetext{
97 Kesterčanek, „Renesansni dvorci”, 147.

98 Sklop zauzima $3100 \mathrm{~m}^{2}$.

99 Gradnja je ugovorena 13. rujna 1577. s majstorima Tomom Ruskovićem, Lukom Nikolićem i Paskom Maričevićem. Unutar kule je dogovorena i gradnja cisterne dužine i širine kule te dubine „kako Vice naloži”. Osim nje u kuli postoji još jedna cisterna (bunar) na četiri svoda, koja je ugovorena prije ove, 22. studenog 1567., s graditeljima Petrom Matkovićem, Stijepom Đivaljevićem i Markom Miloševićem. Podaci o radovima na Vicinu ljetnikovcu su arhivirani, a kronološki ih je poredao i iznio: Kesterčanek, „Renesansni dvorci”, 149-152.

${ }^{100}$ Brinuo se o dobrosusjedskim odnosima, vlasništvu zemlje. Primjerice, 1564. riješio je spor prava puta s vlastelinom Medom Đurđevićem, a 1574. navodnjavanja svojega zemljišta u Šipanskom polju sa susjedom Vladislavom Bunićem. Kesterčanek, „Renesansni dvorci”, 151.
} 


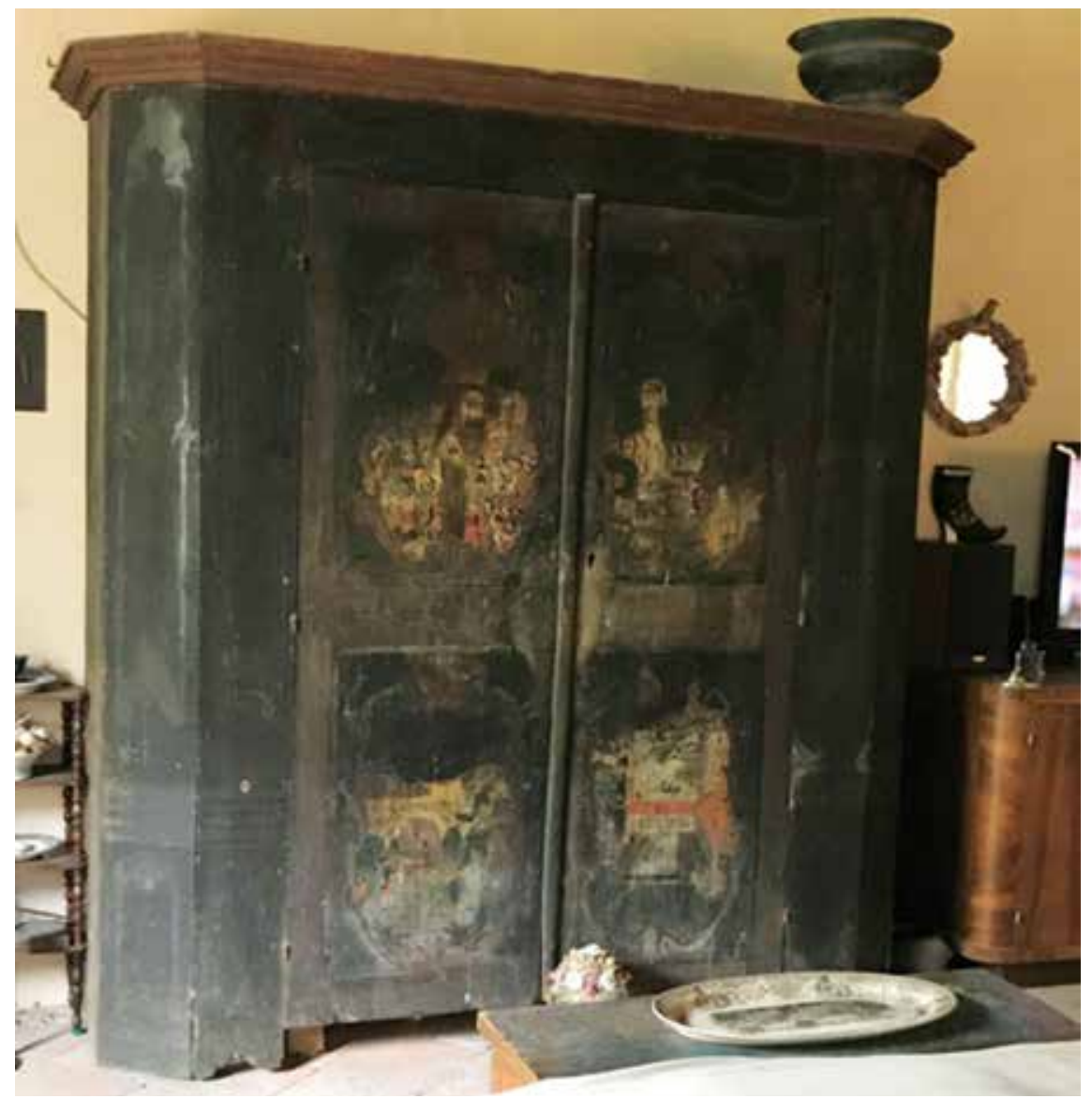

Slika 7. Ormar u Tominoj ladanjskoj kući (foto: Mara Marić) ${ }^{101}$
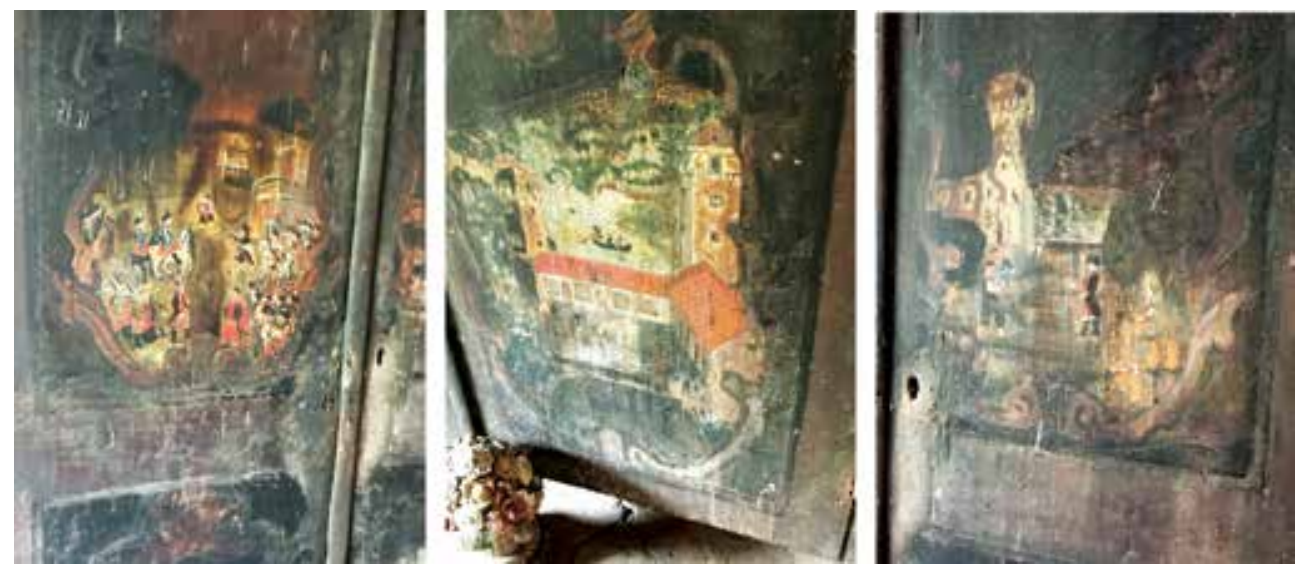

Slike 8, 9 i 10. Detalji s ormara (foto: Mara Marić)

\footnotetext{
${ }^{101}$ Ormar (19. stoljeće) oslikan je kao slika na drvu. Uobičajeno je bilo raditi krednu podlogu koju se oslikavalo temperom.
} 
Zbog ispunjenoga sigurnosnog preduvjeta i svi elementi unutar ladanjskoga sklopa bili su reprezentativniji i raskošniji u odnosu na Tomin ljetnikovac. ${ }^{102} \mathrm{U}$ izgradnji sklopa sudjelovalo je više domaćih graditelja, zidara i kipara: Stijepo Đivaljević (zvan Đivojev), Tomo Rusković, Luka Nikolić i Pasko Maričević. ${ }^{103}$

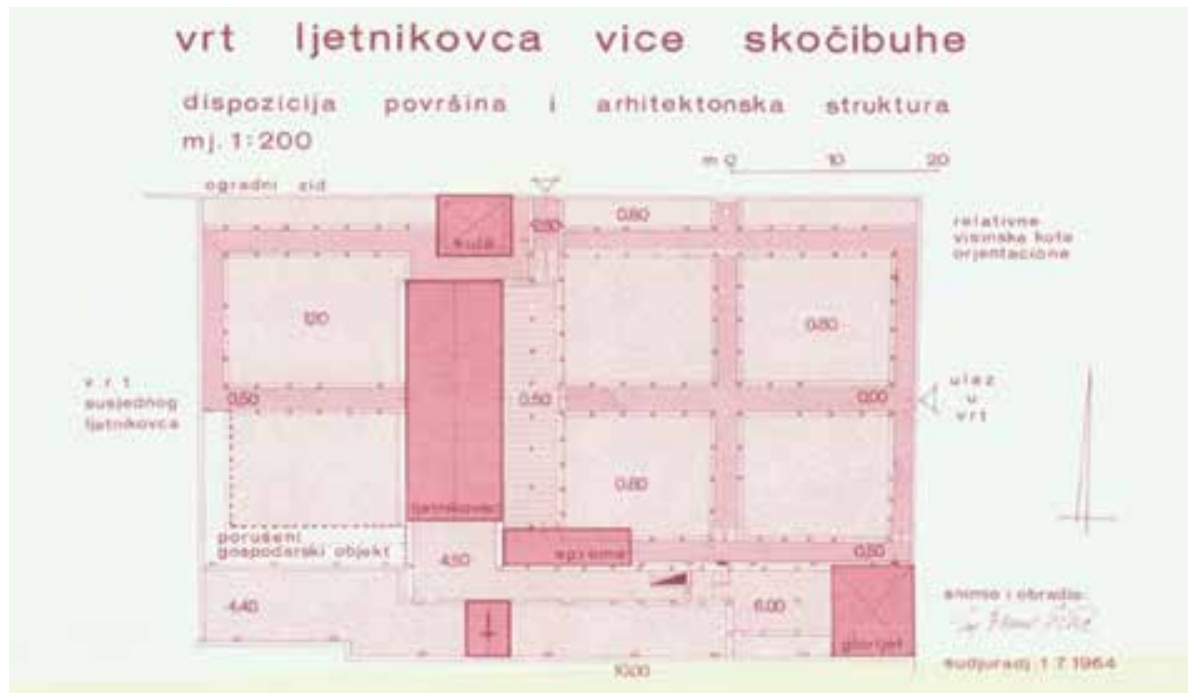

Slika 11. Vicin perivoj (snimka B. Šišića 1864. godine) $)^{104}$

Jednokatna ladanjska kuća građena od korčulanskoga kamena ${ }^{105}$, karakterističnoga L tlocrta, smještena je slobodnostojeće usred prostranoga perivoja (slika 11). ${ }^{106}$ Okomito na kuću postavljeno je krilo dugačke terase ${ }^{107}$, koje je u prizemlju imalo gospodarsku namjenu (mlinica i ostave), a na katu reprezentativne elemente dubrovačke ladanjske arhitekture. Vice je iz svoje spavaće sobe imao izravan pristup na terasu te tako mogao promatrati cijelu uvalu i poslove i u brodogradilištu i u perivoju. Na terasi uz samu kuću Vice je izgradio kapelicu posvećenu sv.

\footnotetext{
${ }^{102}$ Vice je u računskim knjigama zabilježio vrijednost svoje ladanjske cjeline s perivojem i kulom u iznosu od 3.285 zlatnih dukata. Bruno Šišić, „Vrt renesansnog ljetnikovca Vice Stjepovića Skočibuhe u Suđurđu na Šipanu", Dubrovnik 3 (1973): 143.

${ }^{103}$ Podaci o radovima na Vicinu ljetnikovcu su arhivirani, a kronološki ih je poredao i iznio: Kesterčanek, „Renesansni dvorci”, 149-152.

${ }^{104}$ Hrvatska - Državni arhiv u Dubrovniku, Dubrovnik - 859 - Osobni fond Bruna Šišića, ser. 12, podser. 5, br. nacrta: 4. Vrt Skočibuhe, br. kut. 88 .

${ }^{105}$ Kesterčanek, „Renesansni dvorci”, 149.

${ }^{106}$ U Vicinu ljetnikovcu opaža se tipični dubrovački renesansni tlocrt prostorija: prizemlje sa saločom i prvi kat sa salom i četiri sobe (quatro stanze...).

${ }^{107}$ Takav L tlocrt bio je karakterističan za dubrovačke patricijske ljetnikovce, posebice na području gdje su oni građeni uz more, kao primjerice u Rijeci dubrovačkoj, što je omogućavalo da se barkama pristupi zdanju te barka pospremi u spremište (orsan) ispod terase.
} 
Tomi kao uspomenu na oca. ${ }^{108}$ Kapelica je odražavala statusni simbol obitelji, bila je „svojevrsni dokaz i potvrda posjeda - prava na zemlju i na ljude”. ${ }^{109} \mathrm{Na}$ samom kraju terase, prema moru, Vice je dao sagraditi paviljon (pavijun, glorijet). Paviljon se obično nalazio na krajevima terase kao samostalan objekt, a imao je funkciju sjenovitoga odmorišta za opuštanje i uživanje u dalekometnim vizurama. ${ }^{110}$ No Vice kao da nije htio da taj prostor bude potpuno posvećen dokolici, pa se ondje nalazi jedna neobičnost: unutar dijela paviljona na južnoj strani ogradnoga zida nalazi se svećenikov stan (studiolo) (slika 12). ${ }^{11}$

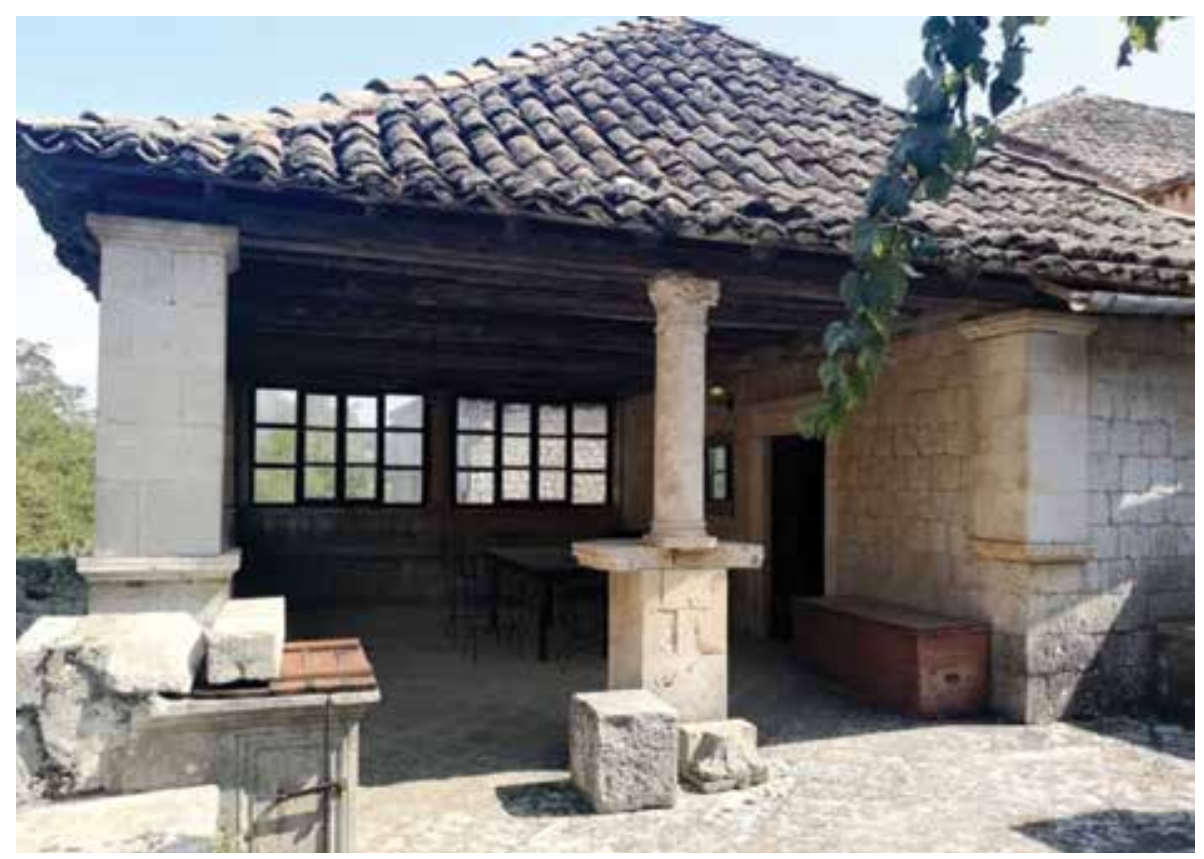

Slika 12. Paviljon na terasi s odvojenim dijelom gdje je bio svećenikov mali stan (foto: Dubravka Mirošević)

${ }^{108}$ Pretpostavlja se da je građena 1570. jer tada Vice ugovara sa slikarom Krstom Antunovićem izradu slike za kapelicu. Izgradnji kapelice posvećivala se jednaka pažnja kao izgradnji ladanjske kuće, pa su i njezini dijelovi bili klesani. Na njezinu pročelju stoji preslica s jednim zvonom i rozeta, a s desne strane ulaznih vrata fino klesana mala škropionica. Kesterčanek, „Renesansni dvorci”, 151.

${ }^{109}$ Grujić, „Ladanjsko-gospodarska arhitektura”, 243.

${ }^{110}$ Paviljon je četverostrešno krovište koje drže niski široki četverostrani kameni stupići izdignuti nižim kamenim zidom, koji je istovremeno imao uzidane kamene klupe na jednom dijelu ili pak cijelom linijom. Vicin je paviljon kao i ladanjska kuća obložen kanalicama, a na samom vrhu je kameni akroterij. S lijeve strane paviljona smještena je cisterna. Grujić, Ladanjska arhitektura dubrovačkog područja, 93; Grujić, Prostori dubrovačke ladanjske arhitekture, 46-47.

${ }^{111}$ Studiolo je prostorija koja je imala zasebnu namjenu. Bio je opremljen namještajem i slikama, a ima i zidni umivaonik i kamin. Suprotno od paviljona i svećenikova stana stoji vanjski toalet. Treba spomenuti i prozor u stanu, koji je specifičan po tome što se otvara na četiri dijela. Grujić, Ladanjska arhitektura dubrovačkog područja, 187. 
Karakteristični L tlocrt sklopa dijeli perivoj na prednji reprezentativni i stražnji vrt, vjerojatno više utilitarnoga karaktera, a pritom glavna šetna staza dijeli sklop na dva sukladna dijela te prolazi prizemljem kroz središte kuće sve do stražnjega vrta, čime su interijer i eksterijer povezani na poseban način. Glavna šetna staza, centralna os toga ladanjskog sklopa, svojom orijentacijom upućuje na komunikaciju prema samoj uvali, prema središtu mjesta.

Perivoj se odlikuje strogom geometrijskom pravilnošću karakterističnom za renesansno razdoblje: u prednjem dijelu poprečne šetnice odjeljuju prostor na četiri pačetvorinasta polja (insule) približno sukladnih veličina. ${ }^{112}$

Sastavni dio perivoja činila je prostrana pergola podignuta na visokim kamenim stupovima s lijepim kruništem ${ }^{113}$, a bila je planirana, ali i izvedena, na cijeloj površini vrta. Iako nije poznat biljni inventar Skočibuhinih vrtova, suvremenik Serafino Razzi naziva ih deliziosi giardini ${ }^{114}$, pa se može pretpostaviti da je ondje bilo zasađeno raznovrsno bilje ${ }^{115}$ budući da je obitelj posjedovala brodove i bavila se trgovinom te je bilo moguće dopremiti za dubrovačko podneblje tada nove vrste. ${ }^{116}$

I uređenje interijera jasno pokazuje Vicin dobar materijalni status. Nekoliko je specifičnih detalja ostalo očuvano do danas: u prozoru na stropu kuhinje nalazi se sunčani sat, a kuhinja je i danas funkcionalna ${ }^{117}$ Kameno stubište u prizemlju odvojeno vratima vodi na prvi kat ladanjske kuće, gdje je velika dvorana (sala, sala grande ${ }^{118}$ za okupljanje ukućana i kućne zabave. Na vrhu stubišta stoji lijepo klesano pilo. U dvorani se nalazi i specifični drveni balatur (unutarnji balkon),

112 Šišić, „Renesansni vrtovi u Suđurđu”, 158.

${ }^{113}$ Stupovi su visine do $1 \mathrm{~m}$ na glavnoj šetnici, a na ostalima su niži. Postavljeni su na svim površinama u gotovo pravilnom razmaku od $3 \mathrm{~m}$, visine $2 \mathrm{~m}$ i promjera $13,5 \mathrm{~cm}$. Pergole koje se nisu mogle nasloniti na stupove oslanjale su se na kamene konzole koje su bile integrirane u ogradni zid perivoja. Takve konzole negdje imaju oblik kamenoga zuba, a negdje su kao četvrtasti plosnati uzidani kamen s okruglim otvorom u sredini. Pergole koje se nalaze poviše predvorja kuće naslanjaju se na nju samu tako da su u zid integrirane kamene kocke u kojima je rupa na koje se oslanja pergola. Šišić, „Vrt renesansnog ljetnikovca", 148-149.

${ }^{114}$ Razzi, Povijest Dubrovnika, 185.

115 Vinova loza „penjala” se po pergolama i imala korisnu ulogu stvarajući hladovinu. Stabla agruma (limuni, gorke naranče, citroni ili četruni) bila su nezaobilazni inventar vrtova jer su imala višestruku funkciju - hranjive, ljekovite i dekorativne vrste. Od cvijeća i dekorativnoga bilja treba izdvojiti ružmarin, ruže, bijeli ljiljan. Korisno bilje često se sadilo s dekorativnim. Šišić, Dubrovački renesansni vrt, 75-86.

${ }^{116}$ Da se radilo o perivoju u kojem je bio moguć „visoki” standard njege pokazuju i ostaci sustava za navodnjavanje u koji se kišnica provodila iz cisterne unutar obrambene kule.

${ }_{117}$ Napa poviše kuhinjskoga ognjišta nosi dim u kružnom smjeru da se s mora, odakle je prijetila potencijalna opasnost, ne bi mogao odrediti smjer. Grujić, Ladanjska arhitektura dubrovačkog područja, 187; Kesterčanek, „Renesansni dvorci”, 148.

${ }^{118}$ Uz saloče (saloccia, saletta) u prizemlju najraskošnije su bile uređene velike glavne prostorije, dvorane (sale) na prvom katu. Grujić, Ladanjska arhitektura dubrovačkog područja, 186. 
jedini sačuvan na dubrovačkom području ${ }^{119}$, koji je dokaz da su se nekad u ljetnikovcima održavali plesovi, maskerate, kazališne predstave i priredbe. ${ }^{120}$

U istoj ravnini uz ladanjsku kuću i sjeverni ogradni zid smještena je obrambena kula, koja se svojom veličinom izdiže iznad svih ladanjskih objekata zdanja, a pristupa joj se pomičnim mostom s prvoga kata kuće. Kula je podignuta na tri kata i sadržava sve odlike renesansnoga vremena u kojem je nastala, pa ju tako krase upečatljivo krunište, niski decentni krov, visoko postavljeni prozori i puškarnice. ${ }^{121}$

Izgradnjom Vicina ladanjskoga zdanja u središtu uvale markiran je nukleus naselja Suđurađ.

\section{Utjecaj obitelji Stjepović-Skočibuha na strukturiranje naselja}

Uvala Suđurađ do dolaska Skočibuha, odnosno gradnje njihovih ladanjskih zdanja, bila je pretežito proizvodni, „industrijski” prostor onoga vremena. Osim ribarenja, na što upućuju ostaci starih orsana, u literaturi se navodi da su se u Suđurđu već od 14. stoljeća izrađivali dijelovi brodova za glavno gruško brodogradilište, a gradili su se i čitavi brodovi. Primjerice, 1335. spominje se gradnja jednoga barkusija (ili barkuzij; najčešći tip broda u 14. stoljeću, srednje veličine, na jedra i vesla). ${ }^{122}$ Naime, gruško brodogradilište ponekad nije moglo prihvatiti brodove većega obujma ili je bilo preopterećeno poslom. ${ }^{123}$

Skočibuhe su svakako dali dodatni impuls brodograđevnoj djelatnosti u Suđurđu. Tijekom 16. stoljeća vlasnik brodogradilišta bio je Tomo Stjepović-Skočibuha. ${ }^{124}$ Poznat je podatak da je 1545. tražio dozvolu za gradnju broda na Šipanu. ${ }^{125} \mathrm{U}$ to

\footnotetext{
${ }^{119}$ Grujić, „Ladanjsko-gospodarska arhitektura”, 242.

${ }^{120}$ Cvito Fisković, Kultura dubrovačkog ladanja (Sorkočevićev ljetnikovac na Lapadu) (Split: Historijski institut Jugoslavenske akademije znanosti i umjetnosti u Dubrovniku, 1966), 36. Maskerata je vrsta prigodne pokladne igre talijanskoga podrijetla, raširena u hrvatskim primorskim komunama $u$ ranom novovjekovlju. Vezana je ponajprije uz pokladne svečanosti i često namijenjena javnom izvođenju, ali se s vremenom razvija u zasebnu literarnu disciplinu, pa su se u njoj okušali i poznati pisci. Pavao Pavličić, „Maskerata”, Leksikon Marina Držića, mrežno izdanje, pristup ostvaren 22. 5. 2020., https://leksikon.muzej-marindrzic.eu/maskerata/.

${ }^{121}$ Kesterčanek, „Renesansni dvorci”, 148.

${ }^{122}$ Prema izvorima, u tom razdoblju često se spominje gradnja barki i barkusija, ali to ne znači da se nisu gradili i ostali tipovi brodova. Boro Kamić, „Neki aspekti privređivanja na dubrovačkim otocima u prošlosti i danas”, Zbornik Dubrovačkog primorja i otoka I (1986): 314; Kraljević, „O naselju Suđurađ na otoku Šipanu”, 81; Pešorda Vardić, „Od barkuzija do galijuna”, 156.

${ }^{123}$ Josip Luetić, Mornarica Dubrovačke Republike (Dubrovnik: Dubrovački odbor za proslavu dvadesetogodišnjice mornarice u redakciji Pomorskog muzeja JAZU u Dubrovniku, 1962), 40.

${ }^{124}$ Kraljević, „O naselju Suđurađ na otoku Šipanu”, 81.

${ }^{125}$ Kesterčanek, „Renesansni dvorci”, 140.
} 
su se vrijeme u brodogradilištu u Suđurđu gradili tipični dubrovački trgovački brodovi, nave, karake i galijuni. ${ }^{126}$ Primjerice, nava Sv. Duh i Sv. Marija Loretska bila je u vlasništvu Antuna Tomina Krivonosovića, a Tomo Stjepović-Skočibuha bio je u posjedu broda Sv. Katarina, poznatog i pod nazivom Skočibuha Veli$k a .{ }^{127}$ Razvoj brodograđevne djelatnosti potaknuo je i neke druge prateće obrte. Primjerice, kovači koji su izrađivali opremu za brodove imali su radionice na predjelu Kovačine. ${ }^{128}$

Uz brodogradnju i obrte vezana je i pomorska trgovina. U 16. stoljeću nava Santo Spirito, čiji je zapovjednik bio Tomo Sagrojević, krcala je teret svijeća i pokrivača za Messinu, a brod Santa Maria della Croce imao je putanju iz Suđurđa za Vieste, gdje je tovario drvenu građu za brodogradilište u Gružu. ${ }^{129}$ Kasnije, u 18. stoljeću, u naselju se pojavljuje i zlatarski obrt. ${ }^{130}$

Gospodarska aktivnost utjecala je i na građevnu djelatnost, odnosno razvoj naselja, koje više nije samo malo ribarsko mjesto ponajprije zahvaljujući Tomi i Vici Stjepoviću-Skočibuhi, čija ladanjska zdanja s kulama znatno mijenjaju fizionomiju uvale u 16. stoljeću, ali i poticanju gradnje stambenih objekata na uzobalnom dijelu uvale.

Ilustrativni prikaz na oltarnoj pali u crkvi sv. Đurđa pokazuje da se uvala gradnjom kula i utvrda, i naravno kuća za trajno prebivalište stanovništva iz unutrašnjosti, počinje doživljavati kao naselje u kojem su kule Skočibuha temeljni orijentiri u prostoru i genius loci cijeloga mjesta (slika 13).

\footnotetext{
${ }^{126}$ Dubrovačka karaka ili argosy tip je jedrenjaka iz 16. stoljeća koji karakterizira veći broj jedara i odvojena uglasta krma. Navodi se da je dubrovačka karaka bila najcjenjenija i najveća, a ime argosies ili engl. argosy dobila je zbog tereta koji je mogla prenijeti. Nava je tip trgovačkoga broda na jedra koji se pojavljuje u 9. i 10. stoljeću. Postoje dva tipa nave: atlantska ili zapadna (naves du Ponant) i sredozemna ili istočna (naves du Levant). Vladislav Brajković, Petar Mardešić, „Dubrovačka karaka“, u: Pomorska enciklopedija, sv. 1 (Zagreb: Jugoslavenski leksikografski zavod, 1972): 462-464; Boro Kamić, „Marginalije na temu. Pomorstvo otoka Šipana”, Naše more 30 (1983), br. 3-4: 117.

${ }^{127}$ Pešorda Vardić, „Od barkuzija do galijuna”, 170.

${ }^{128}$ Kraljević, „O naselju Suđurađ na otoku Šipanu”, 82.

${ }^{129}$ Kamić, „Marginalije na temu”, 123-124.

${ }^{130}$ Kraljević, „O naselju Suđurađ na otoku Šipanu”, 81-82.
} 


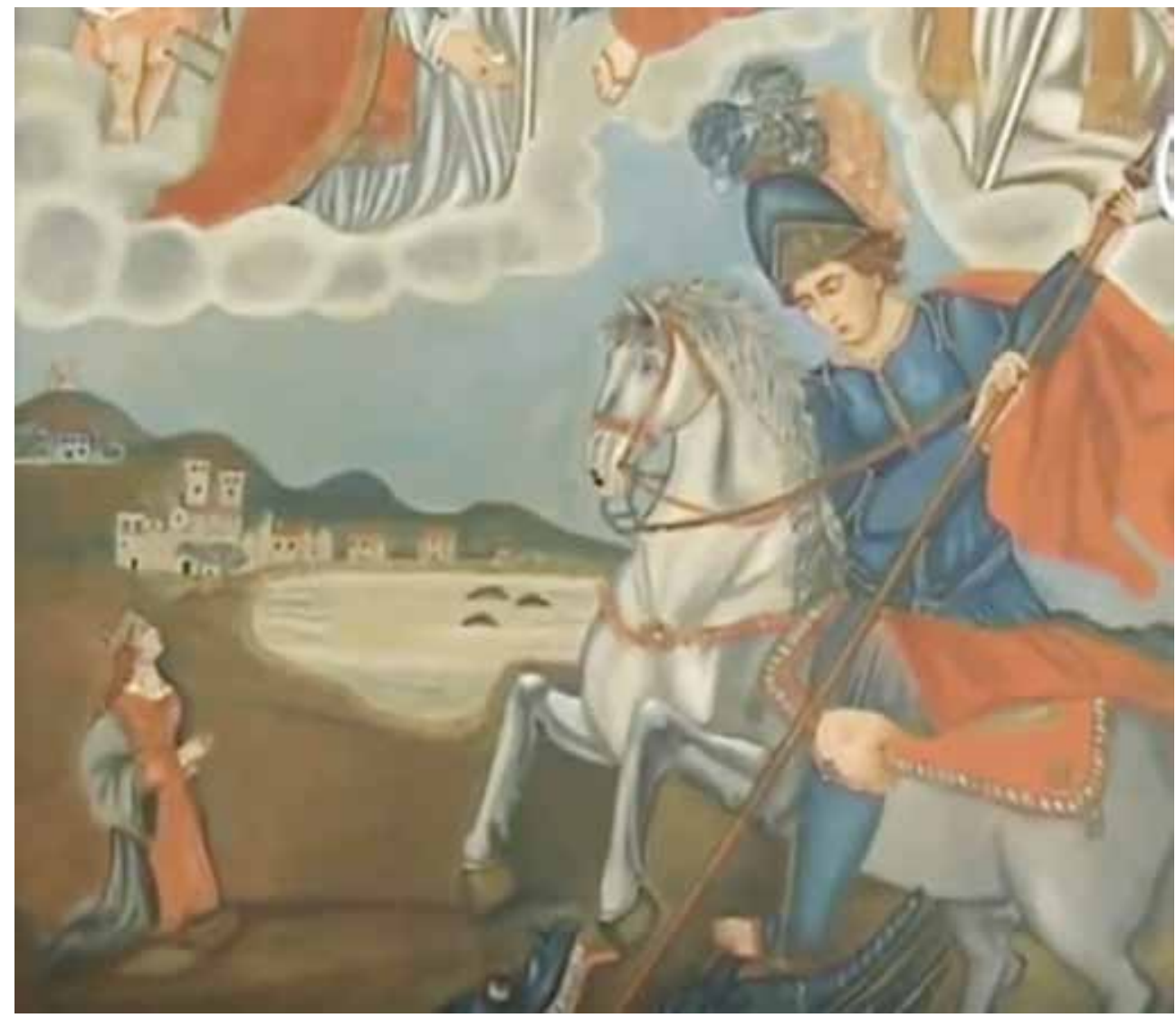

Slika 13. Detalj iz Sv. Đurđa, Sv. Juraj ubija zmaja, nepoznati autor (18. stoljeće)

Za potrebe ovoga rada izrađena je detaljna transkripcija austrijskoga katastra iz 1837. za područje naselja Suđurađ ${ }^{131}$ s ciljem utvrđivanja vlasničkih odnosa i namjene zemljišta u uzobalnom dijelu naselja. Naime, poznato je da se obiteljska stečevina nije prodavala (osim iznimno), pa je pretpostavka da su Skočibuhe odnosno njihovi nasljednici i u 19. stoljeću vlasnici većega dijela naselja Suđurađ. To je potvrđeno provedenom analizom jer je nasljednica Skočibuha, Nikoleta Gučetić r. Fačenda, u prvoj polovini 19. stoljeća još uvijek posjedovala najveći dio posjeda u uvali Suđurađ. Naime, gledajući ukupno vlasništvo čestica u obuhvatu, vlasnica je preko $50 \%$ posjeda i preko $60 \%$ čestica zgrada. Od toga je Nikoleta imala $30 \%$ posjeda i $31 \%$ zgrada u svojem vlasništvu, a $25 \%$ čestica zemlje i 31 $\%$ čestica zgrada u tom je razdoblju prodala (dijagrami 1 i 2 , karta 1).

${ }^{131}$ Detaljno je iščitan opisni dio katastra (izvorno pisan na talijanskom jeziku) te njegov grafički dio. Hrvatska - Državni arhiv u Splitu, Split - fond 152 - Arhiv mapa za Istru i Dalmaciju, K.O. Suđurađ, Zapisnik čestica zemalja, 1837. godina, br. kut. 622. 
Grafikon 1. Vlasnici čestica zemlje u uvali Suđurađ u prvoj polovini 19. stoljeća prema austrijskoj katastarskoj izmjeri iz 1837. godine

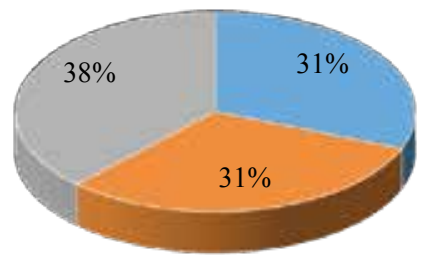

" Nasljednici Skočibuha - Gučetić Nikoleta rođena Fačenda (Gozze Nicoletta nata Facenda)

" Imovina obitelji Skočibuha koja je prodana tijekom 19. stoljeća (Gučetić Nikoleta rođena Fačenda Gozze Nicoletta nata Facenda)

Ostali

Grafikon 2. Vlasnici čestica zgrada u prvoj polovini 19. stoljeća prema austrijskoj katastarskoj izmjeri iz 1837. godine

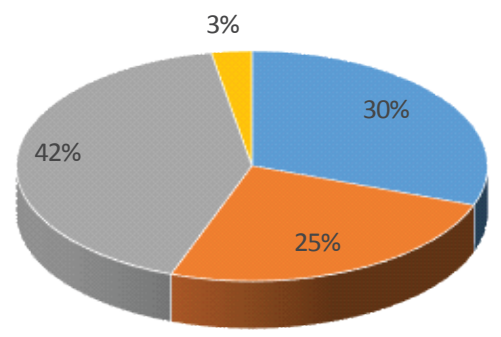

- NasljedniciSkočibuha - Gučetić Nikoleta rođena Fačenda(Gozze Nicoletta nata Facenda)

- Imovina obitelji Skočibuha koja je prodana tijekom 19. stoljeća (Gučetić Nikoleta rođena Fačenda-Gozze Nicoletta nata Facenda)

- Ostali

- Općinsko zemljište 


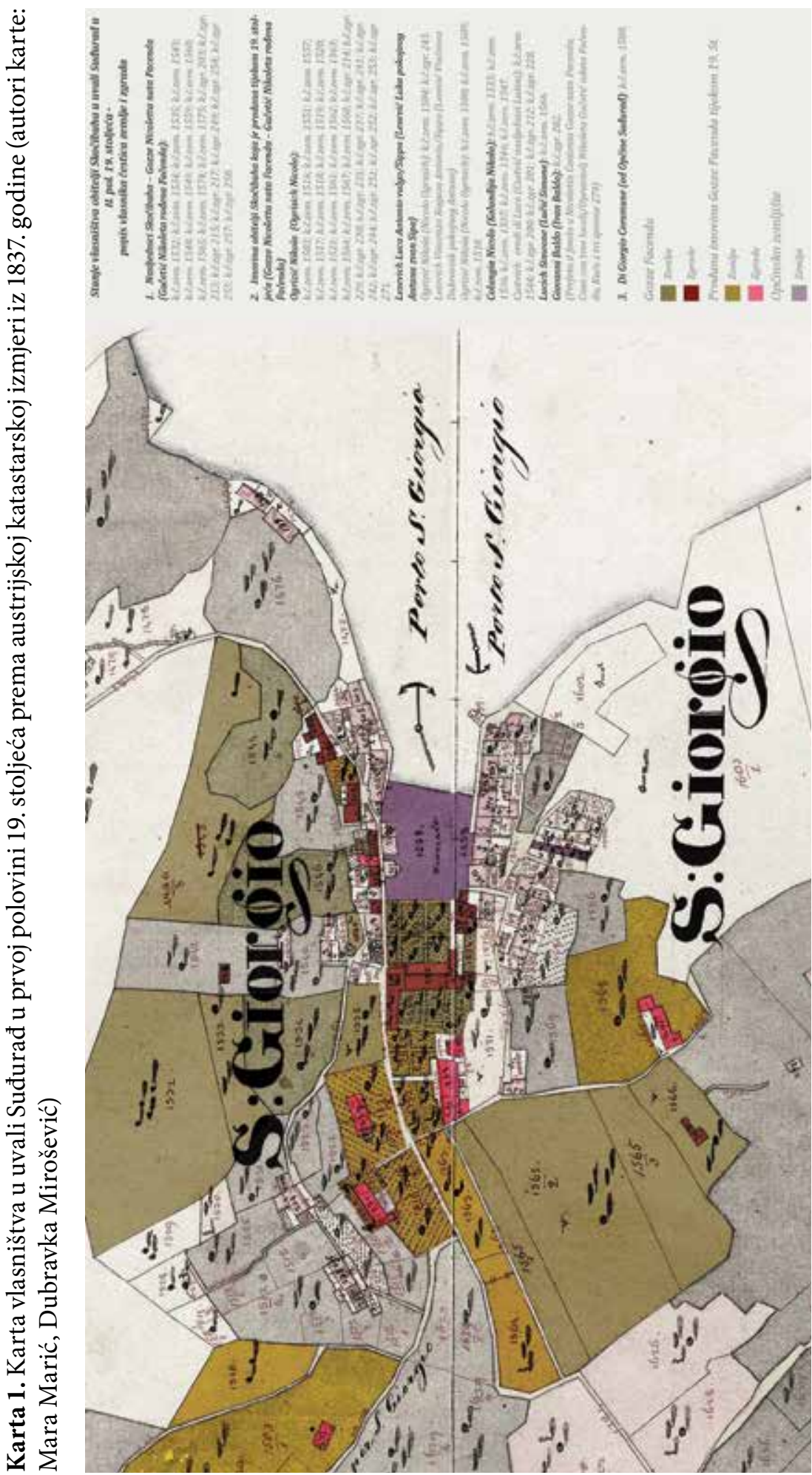


Jednako je važna i analiza namjene iz austrijskoga katastra. U nedostatku bilo kakvih grafičkih dokumenata o zdanjima Skočibuha iz razdoblja Republike, austrijski katastar pokazuje da su sklopovi ljetnikovaca Skočibuha činitelj nukleusa naselja Suđurađ. Stambeni niz naselja širio se sjeverno i južno od Vicina ljetnikovca. Analiza namjene zemljišta pokazuje da je naselje na svojem začelju prema Šipanskom polju imalo tradicionalni otočni agrikulturni karakter: maslinici, vinogradi, pašnjaci i polja (tablica 1, karta 2), ${ }^{132}$ ali pokazuje i jednu vrlo važnu izmjenu karaktera samoga naselja u 19. stoljeću. Naime, u središnjem dijelu naselja, u kojem je bilo brodogradilište obitelji Skočibuha, točno ispred glavnoga ulaza u Vicin ljetnikovac austrijski katastar bilježi trg (Piazzale). Prema tome, Skočibuhe nisu samo izgradnjom svojih prostranih zdanja s utvrdama u središtu uvale trajno obilježili fizionomiju naselja i postali njegov nukleus nego su i definiranjem prostora brodogradilišta i pozicioniranjem pročelja zdanja Vice Stjepovića-Skočibuhe prema brodogradilištu i moru formirali okvir budućega javnog prostora naselja.

\footnotetext{
${ }^{132} \mathrm{Na}$ temelju detaljne transkripcije opisnoga dijela austrijskoga katastra iz 1837. izrađen je skraćeni tablični prikaz u kojem je označeno vlasništvo, broj čestice zemlje, njezina površina, namjena čestica zemlje te čestice zgrada. Površina je izražena u kvadratnom klafteru kao u izvorniku te preračunata u kvadratne metre.
} 
Tablica 1. Skraćena tablica analize austrijskoga katastra

\begin{tabular}{|c|c|c|c|c|}
\hline \multirow{3}{*}{$\begin{array}{l}\text { Vlasništvo (Del } \\
\text { Proprietario) }\end{array}$} & \multicolumn{3}{|c|}{ Zemlja s označenom veličinom i namjenom } & \multirow{3}{*}{$\begin{array}{l}\text { Čestica } \\
\text { zgrade } \\
\left(N^{r o} \text { della }\right. \\
\text { Casa })\end{array}$} \\
\hline & \multirow{2}{*}{$\begin{array}{c}\text { Broj čestice ( } N^{r o} \text { delle Particelle) i namjena } \\
(\text { Del Terreno })\end{array}$} & \multicolumn{2}{|c|}{ Površina $($ Area $)$} & \\
\hline & & $\begin{array}{l}\text { Kvadratni klafter } \\
\text { (Klafter quadrati) }\end{array}$ & $\begin{array}{l}\text { Kvadratni } \\
\text { metar }\left(\mathrm{m}^{2}\right)\end{array}$ & \\
\hline \multirow{11}{*}{$\begin{array}{l}\text { Gučetić Nikoleta } \\
\text { rođena Fačenda } \\
\text { (Gozze Contessa } \\
\text { Nicoletta nata } \\
\text { Facenda) }\end{array}$} & 1532 Pašnjak (Pascolo) & 965 & 3474 & \multirow{11}{*}{$\begin{array}{l}203,213 \\
215,217 \\
249,254 \\
255,257 \\
258\end{array}$} \\
\hline & 1534 Maslinik (Oliveto) & 769 & 2768,4 & \\
\hline & 1535 Maslinik & 275 & 990 & \\
\hline & 1543 Pašnjak & 1256 & 4521,6 & \\
\hline & $1548 \mathrm{Vrt}($ Orto $)$ & 29 & 104,4 & \\
\hline & 1549 Vrt & 23 & 82,8 & \\
\hline & $1559 \mathrm{Vrt}$ & 331 & 1191,6 & \\
\hline & $1560 \mathrm{Vrt}$ & 309 & 1112,4 & \\
\hline & $\begin{array}{l}1565 \text { Vinograd s posađenim maslinama } \\
\text { (Vigna olivata) }\end{array}$ & 690 & 2484 & \\
\hline & $1574 \mathrm{Vrt}$ & 50 & 180 & \\
\hline & 1575 Cisterna & 5 & 18 & \\
\hline \multirow{15}{*}{$\begin{array}{l}\text { Ogrizić Nikola } \\
(\text { Ogrisich Nicolo) }\end{array}$} & 1503 Vinograd s posađenim maslinama & 1531 & 5511,6 & \multirow{15}{*}{$\begin{array}{l}214,229, \\
230,231, \\
237,241, \\
242,244, \\
251,252, \\
253,271\end{array}$} \\
\hline & $1516 \mathrm{Vrt}$ & 366 & 1317,6 & \\
\hline & 1517 Cisterna & 9 & 32,4 & \\
\hline & 1518 Cisterna & 23 & 82,8 & \\
\hline & $1519 \mathrm{Vrt}$ & 55 & 198 & \\
\hline & 1520 Pašnjak & 42 & 151,2 & \\
\hline & 1521 Vinograd s posađenim maslinama & 430 & 1548 & \\
\hline & $1551 \mathrm{Vrt}$ & 75 & 270 & \\
\hline & 1557 Vrt & 15 & 54 & \\
\hline & $1561 \mathrm{Vrt}$ & 166 & 597,6 & \\
\hline & $1562 \mathrm{Vrt}$ & 160 & 576 & \\
\hline & 1563 Vinograd s posađenim maslinama & 404 & 1454,4 & \\
\hline & 1564 Vinograd s posađenim maslinama & 408 & 1468,8 & \\
\hline & 1567 Maslinik & 34 & 122,4 & \\
\hline & 1568 Maslinik & 1180 & 4248 & \\
\hline $\begin{array}{l}\text { Lesević Luka pok. } \\
\text { Antuna zvan Sipa } \\
\text { (Lesevich Luca } \\
\text { Antonio vulgo/Sippa) }\end{array}$ & 1504 Maslinik & 68 & 244,8 & 243 \\
\hline \multirow{3}{*}{$\begin{array}{l}\text { Lesević Vinčenca } \\
\text { Dubrovnik pokojnog } \\
\text { Antuna (Lesevich } \\
\text { Vincenza Ragusa } \\
\text { Antonio/Sippa) }\end{array}$} & 1508 Maslinik & 90 & 324 & \\
\hline & 1509 Maslinik & 9 & 32,4 & \\
\hline & 1510 Pašnjak & 551 & 1983,6 & \\
\hline \multirow{5}{*}{$\begin{array}{l}\text { Kolunđija Nikola } \\
\text { (Colungia Nicolo) }\end{array}$} & 1533 Pašnjak & $458(498) ?$ & & \\
\hline & 1536 Neplodna zemlja (Sterille) & 26 & 93,6 & \\
\hline & 1537 Neplodna zemlja (Sterille) & 42 & 151,2 & \\
\hline & 1546 Maslinik & 806 & 2901.6 & \\
\hline & $1547 \mathrm{Vrt}$ & 17 & 61,2 & \\
\hline $\begin{array}{l}\text { Custvić nasljednici } \\
\text { Lukini (Custvich } \\
\text { eredi di Luca) }\end{array}$ & 1544 Maslinik & 694 & 2498,4 & $\begin{array}{l}200,201 \\
212,228\end{array}$ \\
\hline $\begin{array}{l}\text { Lučić Simone } \\
\text { (Lucich Simeone) }\end{array}$ & 1566 Maslinik & 535 & 1926 & \\
\hline $\begin{array}{l}\text { Ivan Baldo (Giovanni } \\
\text { Baldo) }\end{array}$ & & & & 202 \\
\hline $\begin{array}{l}\text { Općina Suđurađ ( } \mathrm{Di} \\
\text { Giorgio Commune) }\end{array}$ & $1588 \operatorname{Trg}$ (Piazzale) & 725 & 2610 & \\
\hline
\end{tabular}




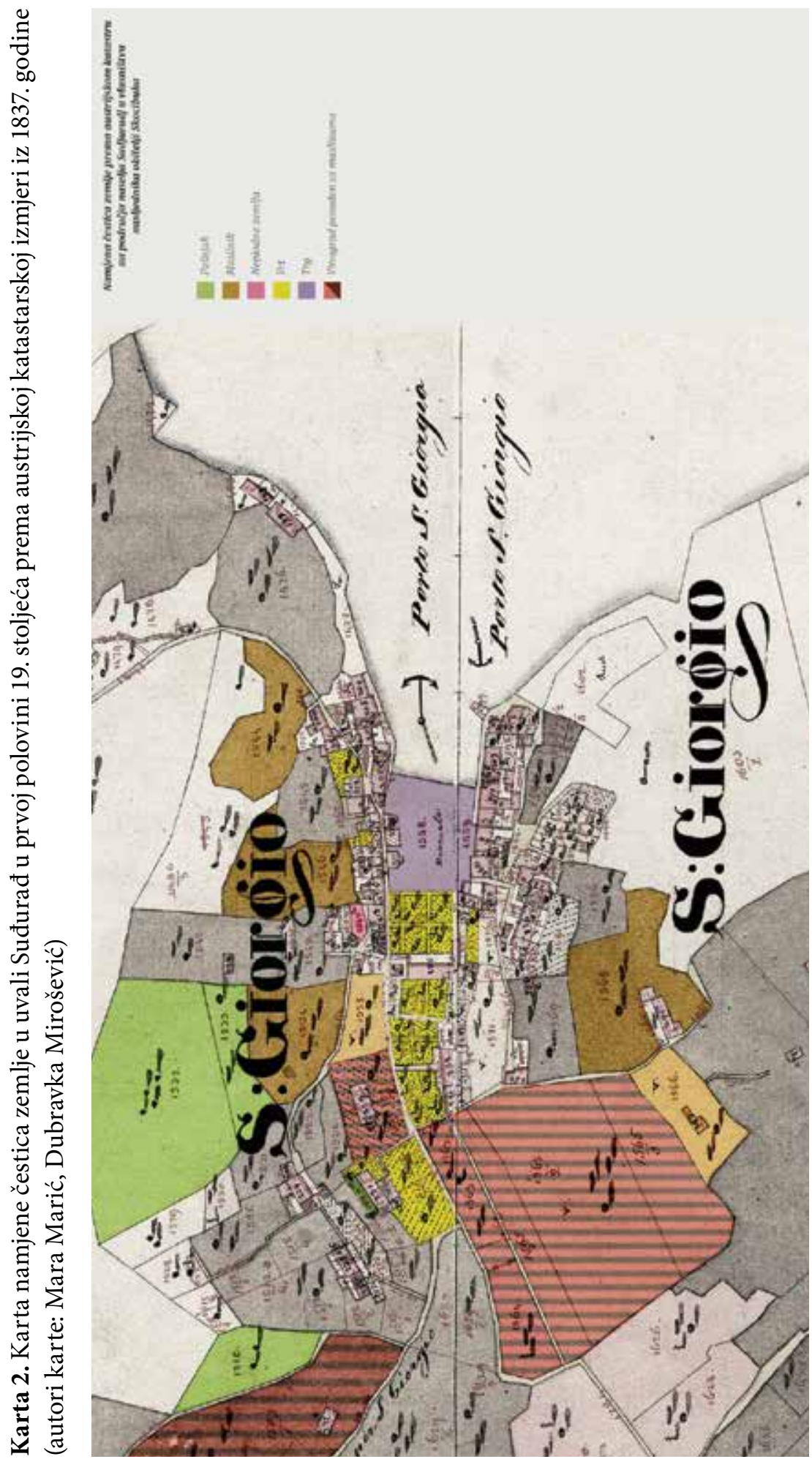




\section{Zaključak}

Suđurađ je smješten u uvali na jugoistočnoj strani otoka Šipana. Tijekom povijesti pokazao se pogodnim mjestom za život jer je uvala prirodno zaštićena od vjetrova i utjecaja s mora. U najstarijoj povijesti Suđurađ je bio mala luka gdje su se stanovnici primarno bavili ribarstvom, na što upućuje i naziv De portu sancti Georgii.

Elafitska otočna naselja općenito nemaju urbani karakter jer se radi o malim otocima, na relativno maloj udaljenosti od Dubrovnika, pa je i Suđurađ donekle tipično uzobalno naselje. Prema tipologiji gradnje, radi se većinom o sklopovima kuća u nizu. Izgradnjom Tomina ladanjskoga zdanja u središnjem dijelu uvale Suđurađ 1529. započinje razdoblje strukturiranja naselja Suđurađ. Iako je Tomin ljetnikovac bio smješten dublje prema obali u odnosu na ostale na tom dijelu Šipana, njegova orijentacija (orijentacija kuće i glavne šetnice u perivoju) prema glavnoj otočnoj komunikaciji i Šipanskom polju, nasuprot Getaldićevu ljetnikovcu, sugerira da tada naselje Suđurađ još uvijek nije dobilo svoje završne konture, odnosno funkciju trajnoga naselja. Naime, tada još nije bilo dovoljno sigurno smjestiti kuću neposredno uz obalu te položiti pročelje kuće prema moru.

Nadgradnja dotad maloga ribarskog naselja počela je naseljavanjem stanovnika na Vicin poticaj. Da bi se naselje moglo trajno naseliti stanovništvom, trebalo je osigurati određene sigurnosne uvjete. Zbog toga Vice nakon očeve smrti daje sagraditi kulu (1569.) unutar cjeline očeva ljetnikovca. Kula je imala obrambenu, stambenu i promatračku funkciju. Orijentacija i organizacija Vicina ljetnikovca koji počinje graditi 1561. pokazuju da se tada naselje počinje snažnije strukturirati. Vice ljetnikovac orijentira prema uvali, prema moru, i pritom naglašava fortifikacijske elemente svojega zdanja. Glavna šetna staza u perivoju, kao okosnica posjeda koja dijeli i perivoj i kuću na gotovo simetrične dijelove, započinje na ogradnome zidu okrenutom prema moru, što postaje glavni ulaz u posjed. Objekti u ljetnikovcu sugeriraju da se u perivoju moglo uživati u pogledu na more - Vice postavlja paviljon na kraju terase s pogledom na more. Za razliku od drugih ljetnikovaca, smješten u centralnom dijelu naselja, u produžetku očeva, tik do nekadašnjega škara, već položajem sugerira važnost vlasnika za mjesto.

Da bi osigurao sigurnost uvale, Vice je sudjelovao i u gradnji crkve-utvrde Sv. Duha, koja je također bila u funkciji promatračnice i pribježišta. Sve to stvorilo je preduvjete za trajnije nastanjivanje naselja, što je bio Vicin cilj.

Iščeznućem prezimena Skočibuha (1644.) bogatstvo i zdanja nasljeđuje obitelj Fačenda, čija je posljednja nasljednica bila Nikoleta Gučetić r. Fačenda, koja umire 1863., kada se nasljednici zdanja mijenjaju.

Otočno stanovništvo rijetko je kad posjedovalo zemlju, najčešće su radili na crkvenoj ili zemlji plemićkih i bogatijih građanskih obitelji. Stoga analiza austrijskoga katastra iz 1837. pokazuje da su i u prvoj polovini 19. stoljeća nasljednici Skočibuha posjedovali veliki dio Suđurđa, što je čvrst pokazatelj da su Skočibuhe bili presudni za razvoj naselja. 


\section{Neobjavljeni izvori}

Genealoška baza podataka Nenada Vekarića.

Hrvatska - Državni arhiv u Dubrovniku, Dubrovnik - 63 - Poslovni dokumenti iz privatnih arhiva (Privata).

Hrvatska - Državni arhiv u Dubrovniku, Dubrovnik - 859 - Osobni fond Bruna Šišića.

Hrvatska - Državni arhiv u Splitu, Split - fond 152 - Arhiv mapa za Istru i Dalmaciju.

\section{Literatura}

„Arion”. Hrvatska enciklopedija, mrežno izdanje. Leksikografski zavod „Miroslav Krleža". Pristup ostvaren 20. 5. 2020. https://www.enciklopedija.hr/natuknica.aspx?id=3803.

Bačić, Jurica. „Stjepović-Skočibuha (Dubrovačka Republika od konca 15. do pred kraj 16. stoljeća)”. Zbornik Dubrovačkog primorja i otoka III (1991): 157-186.

Božanić, Joško. „Stil, priča, leksik, svijet tezaurusa usmene predaje komiškog ribara Ivana Vitaljića Gusle”. Čakavska rič 38 (2010), br. 1-2: 5-122.

Brajković, Vladislav; Mardešić, Petar. „Dubrovačka karaka”. U: Pomorska enciklopedija, svezak 1, Zagreb: Jugoslavenski leksikografski zavod, 1972.

Cvjetković, Aida. Mirisi, boje i orisi otoka Šipana. Dubrovnik: Vlast. nakl., 2003.

Cvjetković, Božo. Estetska oceanografija (ljepota mora i obale). Dubrovnik: Komisijonalna naklada štamparije De Giulli i dr., 1920.

Čapeta, Ivana. „Doprinos djelatnosti radionice Santa Croce”. Peristil: zbornik radova za povijest umjetnosti 51 (2008), br. 1: 159-168.

Fisković, Cvito. Kultura dubrovačkog ladanja (Sorkočevićev ljetnikovac na Lapadu). Split: Historijski institut Jugoslavenske akademije znanosti i umjetnosti u Dubrovniku, 1966.

Fisković, Igor. „Bilješke o starokršćanskim i ranosrednjovjekovnim spomenicima na otoku Šipanu”. Prilozi povijesti umjetnosti u Dalmaciji 18 (1970), br. 1: 5-29.

Foretić, Vinko. Povijest Dubrovnika do 1808., svezak 1. Zagreb: Matica hrvatska, 1980.

Grujić, Nada. Prostori dubrovačke ladanjske arhitekture. Zagreb: Razred za likovne umjetnosti JAZU, 1982.

Grujić, Nada. „Reprezentativna stambena arhitektura”. U: Zlatno doba Dubrovnika - XV. i XVI. stoljeće, uredio Vladimir Marković, 65-75. Zagreb; Dubrovnik: Muzejski prostor Zagreb; Dubrovački muzej, 1987. 
Grujić, Nada. „Ladanjsko-gospodarska arhitektura 15. i 16. stoljeća na otoku Šipanu". Zbornik Dubrovačkog primorja i otoka II (1988): 223-274.

Grujić, Nada. „Ljetnikovac Vice Stjepovića-Skočibuhe kod Tri crkve u Dubrovniku: Ishodište arhitektonskog tipa”. Radovi Instituta za povijest umjetnosti 12-13 (1988): 215-227.

Grujić, Nada. Ladanjska arhitektura dubrovačkog područja. Zagreb: Institut za povijest umjetnosti Sveučilišta; Nakladni zavod Matice hrvatske, 1991.

Harris, Robin. Povijest Dubrovnika. Zagreb: Golden marketing - Tehnička knjiga, 2006.

Ivančević, Radovan. „Iskustvo renesanse za (bolje) suvremene i buduće ceste”. Ceste i mostovi 41 (1995), br. 9-10: 293.

Kamić, Boro. „Ribarstvo otoka Šipana nekad i sad”. Naše more 29 (1982), br. 6: 265-278.

Kamić, Boro. „Marginalije na temu. Pomorstvo otoka Šipana”. Naše more 30 (1983), br. 3-4: 115-134.

Kamić, Boro. „Orsani otoka Šipana”. Naše more 30 (1983), br. 6: 259-270.

Kamić, Boro. „Neki aspekti privređivanja na dubrovačkim otocima u prošlosti i danas". U: Zbornik Dubrovačkog primorja i otoka I (1986): 301-331.

Karamehmedović, Deša. „Prostorna i funkcionalna klasifikacija dubrovačke ladanjske arhitekture: doprinos društvenom vrednovanju”. Anali Zavoda za povijesne znanosti Hrvatske akademije znanosti i umjetnosti u Dubrovniku 53/2 (2015): 459-487.

Kesterčanek, Frano. „Tragom jednog Michelangelovog djela u Dubrovniku”. Prilozi povijesti umjetnosti u Dalmaciji 11 (1959), br. 1: 59-71.

Kesterčanek, Frano. „Renesansni dvorci obitelji Stjepovića-Skočibuhe na Šipanu". Anali Historijskog instituta JAZU u Dubrovniku VIII-IX (1962): 139-152.

Kraljević, Marija. „O naselju Suđurađ na otoku Šipanu”. Zbornik Dubrovačkog primorja i otoka VII (1999): 78-90.

Krivošić, Stjepan. Stanovništvo Dubrovnika i demografske promjene u prošlosti. Dubrovnik: Zavod za povijesne znanosti JAZU u Dubrovniku, 1990.

Lučić, Josip. „Građevinski spomenici XIII stoljeća na Šipanu”. Prilozi povijesti umjetnosti u Dalmaciji 13 (1961), br. 1: 78-84.

Lučić, Josip. „Prošlost elafitskog otoka Šipana (do 1300.) godine”. Starohrvatska prosvjeta 3 (1968), br. 10: 93-163.

Luetić, Josip. Mornarica Dubrovačke Republike. Dubrovnik: Dubrovački odbor za proslavu dvadesetogodišnjice mornarice u redakciji Pomorskog muzeja JAZU u Dubrovniku, 1962. 
Luetić, Josip. Pomorci i jedrenjaci Republike Dubrovačke. Zagreb: Nakladni zavod Matice hrvatske, 1984.

Masi, Gianluca. „Scoccibucca (Skocibuha) and Faccenda (Facenda), Two Families of Shipowners and Merchants in Ragusa (Dubrovnik) between 16th and 17th Century". U: L'Italia e la frontiera orientale dell'Europa, 1204-1669 = Italy and Europe's Eastern Border, 1204-1669, uredili Iulian Miha Damian, Ioan Aurel Pop, Mihailo St. Popović i Alexandru Simon, 259-282. Frankfurt am Main; Berlin; Bern; Bruxelles; New York; Oxford; Beč: Peter Lang Verlag, 2012.

Mioč, Boro; Ivanković, Ante; Pavić, Vesna; Barać, Zdravko; Sinković, Karmen; Marić, Ivica. „Odlike eksterijera dubrovačke ovce”. U: Knjiga priopćenja sa XXXVIII. znanstvenog skupa hrvatskih agronoma, uredio Tito Žimbrek, 491-494. Zagreb: Hrvatsko agronomsko društvo, 2003.

Nadilo, Branko. „Razvitak hrvatskih otoka. Otoci uokolo Dubrovnika”. Građevinar 52 (2000), br. 10: 617-630.

Pavličić, Pavao. „Maskerata”. Leksikon Marina Držića, mrežno izdanje. Pristup ostvaren 22. 5. 2020. https://leksikon.muzej-marindrzic.eu/maskerata/.

Pelc, Milan. „Fortuna s 'grba' Skočibuha - identitet i mentalitet trgovaca u renesansnom Dubrovniku”. U: Metamorfoze mita. Mitologija u umjetnosti od srednjega vijeka do moderne (Zbornik radova znanstvenog skupa "Dani Cvita Fiskovića” održanog 2010. godine), uredili Dino Milinović i Joško Belamarić, 67-76. Zagreb: Odsjek za povijest umjetnosti Filozofskog fakulteta Sveučilišta u Zagrebu, 2012.

Pelivan, Ante. „Elafiti: nepoznato otočje”. Ekološki glasnik 6 (1996/1997): 7-19.

Pešorda Vardić, Zrinka. „Od barkuzija do galijuna: Nekoliko crtica o ulozi pomorstva u usponu dubrovačkoga građanstva u kasnome srednjem i ranome novom vijeku”. Povijesni prilozi 33 (2014), br. 47: 143-181.

Planić-Lončarić, Marija. „Suđurađ i Luka na otoku Šipanu”. Zbornik Dubrovačkog primorja i otoka III (1991): 113-129.

Posedel, Josip. „Predromanički spomenici otoka Šipana”. Starohrvatska prosvjeta 3 (1952), br. 2: 113-128.

Prijatelj, Kruno. „O autoru Skočibuhine pale u dubrovačkih dominikanaca”. Peristil: zbornik radova za povijest umjetnosti 6-7 (1963), br. 1: 67-70.

Prosperov Novak, Slobodan. Dubrovnik iznova. Zagreb: Sveučilišna naklada Liber; Međunarodni slavistički centar SRH, 1987.

Puhiera, Samuilo. „Srednjovekovne crkve na ostrvu Šipanu kod Dubrovnika”. Starinar NS V-VI (1954/55): 227-245.

Razzi, Serafino. Povijest Dubrovnika. Dubrovnik: Matica hrvatska, Ogranak Dubrovnik, 2011. 
Skok, Petar. Slavenstvo i romanstvo na jadranskim otocima. Zagreb: Jadranski institut JAZU, 1950.

Stojan, Slavica. Ombla, vile i vilani. Povijest svakodnevnice u ljetnikovcima Rijeke dubrovačke (15. do 19. st.). Zagreb; Dubrovnik: Hrvatska akademija znanosti i umjetnosti, Zavod za povijesne znanosti u Dubrovniku, 2018.

Šišić, Bruno. „Vrt renesansnog ljetnikovca Vice Stjepovića Skočibuhe u Suđurđu na Šipanu". Dubrovnik 3 (1973): 139-151.

Šišić, Bruno. Dubrovački renesansni vrt: nastajanje i oblikovna obilježja. Dubrovnik: Hrvatska akademija znanosti i umjetnosti, Zavod za povijesne znanosti u Dubrovniku, 1991.

Šišić, Bruno. „Renesansni vrtovi u Suđurđu na otoku Šipanu”. U: Simpozij Povijesni vrtovi, perivoji i parkovi primorske Hrvatske, uredio Dražen Grgurević, 155-159. Split: Franjo Kluz d.d. Omiš, 1998.

Šitina, Ana. „Opus Bernardina Ricciardija na istočnoj jadranskoj obali”. Ars Adriatica 7 (2017): 195-209.

„Vasari, Giorgio”. Hrvatska enciklopedija, mrežno izdanje. Leksikografski zavod „Miroslav Krleža”. Pristup ostvaren 21. 5. 2020. https://www.enciklopedija.hr/ natuknica.aspx?id=63953.

Vekarić, Nenad. Vlastela grada Dubrovnika. Korijeni, struktura i razvoj dubrovačkog plemstva, svezak 8. Zagreb; Dubrovnik: Hrvatska akademija znanosti i umjetnosti, Zavod za povijesne znanosti u Dubrovniku, 2017.

Veramenta, Patricija. „Grobnica obitelji Federika Glavića na Boninovu”. Anali Zavoda za povijesne znanosti Hrvatske akademije znanosti i umjetnosti u Dubrovniku 50 (2012): 339-363. 


\author{
Mara Marić ${ }^{*}$ \\ Dubravka Mirošević
}

\title{
Impact of the Stjepović-Skočibuha Family on the Urban Structuring of Suđurađ on the Island of Šipan
}

\section{Summary}

The paper focuses on the impact of the Stjepović-Skočibuha family in shaping the settlement of Suđurađ on the island of Šipan near Dubrovnik. It discusses the social, economic, and cultural context of Šipan in the 16th century, with special reference to the development of Suđurađ. Biographical data of the progenitors of the Stjepović-Skočibuha family are presented, who are merited with the construction of two representative summerhouse and economy assemblies in the settlement, which over time became the main landmarks of Suđurad. The starting hypothesis of the research is that the summerhouse assemblies of Tomo and especially Vice Stjepović-Skočibuha significantly influenced the urban structuring of the settlement. The stylistic characteristics and organization of the two building assemblies and the associated lands have been analysed in relation to the settlement, with a detailed transcription of the Austrian cadastre from the first half of the 19th century, including an analysis of land ownership and uses of individual land plots, which confirmed the starting hypothesis. The heirs of the family were still the majority owners of buildings and land plots in Suđurad at the time.

Keywords: Šipan, Suđurađ, summerhouse and economy buildings of the Skočibuha family, Tomo and Vice Stjepović-Skočibuha, urban structuring

\footnotetext{
Mara Marić, Department of Mediterranean Cultures, Marka Marojice 4, 20000 Dubrovnik, Croatia,E-mail: mara.maric@unidu.hr

** Dubravka Mirošević, 20000 Dubrovnik, E-mail: mirosevic.dubravka@gmail.com
} 